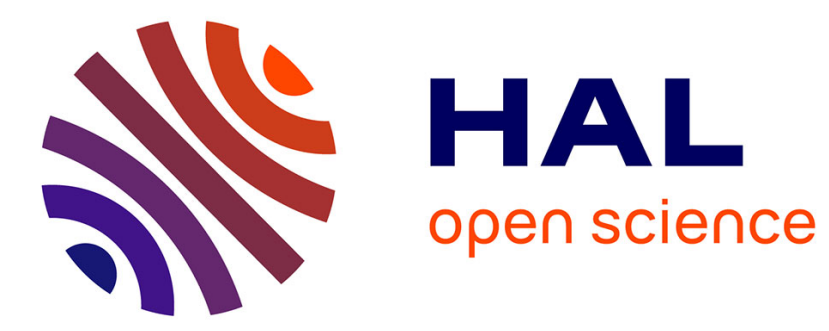

\title{
Salar de Atacama basin: A record of compressional tectonics in the central Andes since the mid-Cretaceous
}

César Arriagada, Peter R. Cobbold, Pierrick Roperch

\section{To cite this version:}

César Arriagada, Peter R. Cobbold, Pierrick Roperch. Salar de Atacama basin: A record of compressional tectonics in the central Andes since the mid-Cretaceous. Tectonics, 2006, 25 (1), pp.TC1008. 10.1029/2004TC001770 . hal-00115642

\section{HAL Id: hal-00115642 \\ https://hal.science/hal-00115642}

Submitted on 29 Jun 2016

HAL is a multi-disciplinary open access archive for the deposit and dissemination of scientific research documents, whether they are published or not. The documents may come from teaching and research institutions in France or abroad, or from public or private research centers.
L'archive ouverte pluridisciplinaire HAL, est destinée au dépôt et à la diffusion de documents scientifiques de niveau recherche, publiés ou non, émanant des établissements d'enseignement et de recherche français ou étrangers, des laboratoires publics ou privés. 


\title{
Salar de Atacama basin: A record of compressional tectonics in the central Andes since the mid-Cretaceous
}

\author{
Cesar Arriagada, ${ }^{1,2}$ Peter R. Cobbold, ${ }^{1}$ and Pierrick Roperch ${ }^{3}$ \\ Received 18 November 2004; revised 11 November 2005; accepted 22 November 2005; published 23 February 2006.
}

[1] The Salar de Atacama basin lies in the inner fore arc of northern Chile. Topographically and structurally, it is a first-order feature of the central Andes. The sedimentary fill of the basin constrains the timing and extent of crustal deformation since the midCretaceous. We have studied good exposures along the western edge of the basin and have correlated them with seismic reflection sections and data from an exploration well. Throughout most of its history, the basin developed in a foreland setting, during periods of thin-skinned and thick-skinned thrusting. Growth strata provide evidence for coeval sedimentation and thrust motions during mid-Cretaceous, Paleogene, and Neogene times. Pre-Neogene deformation was significant in the basin and in surounding areas of the early central Andes. Models that attempt to explain the current thickness of the central Andes should consider Late Cretaceous and Paleogene shortening, as well as the more obvious Neogene and Quaternary shortening. Citation: Arriagada, C., P. R. Cobbold, and P. Roperch (2006), Salar de Atacama basin: A record of compressional tectonics in the central Andes since the mid-Cretaceous, Tectonics, 25, TC1008, doi:10.1029/ 2004TC001770.

\section{Introduction}

[2] The Andean Cordillera extends for some $8000 \mathrm{~km}$ along the western margin of South America and is the longest subaerial mountain chain on Earth. Since the early days of plate tectonics, the Andes have been cited as the typical products of an active continental margin, between oceanic and continental plates [Dewey and Bird, 1970]. The most striking features of the mountain belt are the Altiplano-Puna, a high continental plateau second only to the Tibetan plateau in its area and average elevation [Allmendinger et al., 1997], and a $55^{\circ}$ bend known as the Bolivian Orocline or Arica elbow (Figure 1).

\footnotetext{
${ }^{1}$ Géosciences-Rennes, UMR6118 du CNRS, Rennes, France.

${ }^{2}$ Now at Departamento de Geología, Universidad de Chile, Santiago, Chile.

${ }^{3}$ Institut de Recherche pour le Développement, UR154, Géosciences Rennes, Rennes, France.

Copyright 2006 by the American Geophysical Union. 0278-7407/06/2004TC001770
}

[3] Under the central Andes the crust is exceptionally up to $70 \mathrm{~km}$ thick [James, 1971]. The crustal root is thought to be primarily a result of tectonic shortening and thickening [Isacks, 1988; Sheffels, 1990; Schmitz, 1994; Lamb and Hoke, 1997]. Most authors have considered that shortening in the central Andes is dominantly of Neogene age, especially in the Eastern Cordillera and Sub-Andean Zone [Isacks, 1988; Semperé et al., 1990; Gubbels et al., 1993; Schmitz, 1994; Allmendinger et al., 1997; Baby et al., 1997; Lamb and Hoke, 1997; Kley, 1999]. However, there is evidence that shortening started as early as the Late Cretaceous or early Paleocene [Coney and Evenchick, 1994; Semperé, 1995; Semperé et al., 1997; Horton and DeCelles, 1997; Horton et al., 2001; Coutand et al., 2001; McQuarrie and DeCelles, 2001; Müller et al., 2002; Cobbold et al., 2006].

[4] On the western side of the central Andes, the lowlying fore arc is still poorly understood. Little deformation seems to have occurred there since $10 \mathrm{Ma}$, although recent work in the outer fore arc of northern Chile has demonstrated late Miocene to Quaternary shortening parallel to the plate boundary and perpendicular extension [González et al., 2003; Allmendinger et al., 2005]. In contrast, there is structural, stratigraphic and paleomagnetic evidence for more intense deformation and mountain building in the inner fore arc of northern Chile between the Late Cretaceous and the Neogene [Chong and Reutter, 1985; Hammerschmidt et al., 1992; Hartley et al., 1992; Scheuber and Reutter, 1992; Charrier and Reutter, 1994; Somoza et al., 1999; Arriagada et al., 2000; Randall et al., 2001; Somoza and Tomlinson, 2002; Arriagada et al., 2003; C. Arriagada et al., Paleomagnetism and tectonics of the southern Atacama Desert $\left(25^{\circ}-28^{\circ} \mathrm{S}\right)$, northern Chile, submitted to Tectonics, 2005, hereinafter referred to as Arriagada et al., submitted manuscript, 2005]. What was the style of this deformation? What was its timing?

[5] In an attempt to answer these questions, we have focused attention on the intermontane Salar de Atacama basin, which contains an unusually complete record of sedimentation and coeval deformation (Figures 1,2a and $2 b)$. The basin belongs to the present-day inner fore arc, but originally formed in a foreland position. At an average elevation of $2300 \mathrm{~m}$, the basin is much lower than the Puna $(\sim 4400 \mathrm{~m})$ or the Western Cordillera (up to $6500 \mathrm{~m}$ ). Topographically, the Salar de Atacama stands out as a major depression on the generally smooth western slope of the central Andes [Isacks, 1988; Gephart, 1994; Götze and Krause, 2002; Yuan et al., 2002]. It is some $200 \mathrm{~km}$ long and $100 \mathrm{~km}$ wide. Seismic reflection profiling has shown 


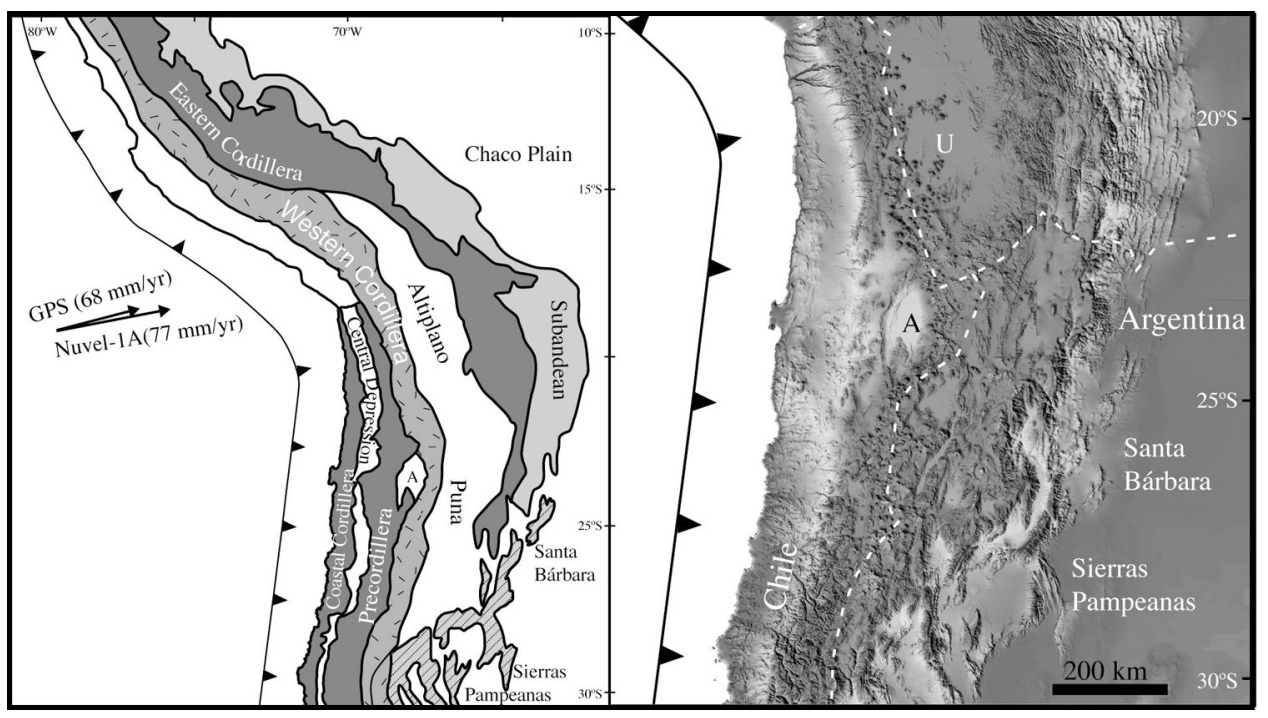

Figure 1. Relief and structure of southern central Andes. From west to east, continental margin at about $15-27^{\circ} \mathrm{S}$ consists of Peru-Chile trench and continental slope; Coastal Cordillera, a remnant of a Mesozoic magmatic arc; Central Depression or Pampa del Tamarugal, an inner fore-arc basin; Precordillera (including Cordillera Domeyko) and Pre-Andean Depression (including Salar de Atacama basin); Western Cordillera, an active volcanic arc along eastern border of Chile; Altiplano-Puna plateau, a high-elevation hinterland plateau; Eastern Cordillera, a rugged internal fold-and-thrust belt; Sub-Andean Zone and Santa Barbara Zone, frontal active parts of eastern fold-and-thrust belt; and Beni Plain and Chaco Plain, parts of a low-elevation foreland basin underlain by Brazilian shield. A, Salar de Atacama; U, Salar de Uyuni. Arrows represent convergence between Nazca and South America (NUVEL-1A vector of DeMets et al. [1994], GPS vector of Norabuena et al. [1997]).

that it contains as much as $8 \mathrm{~km}$ of sediment [Macellari et $a l ., 1991]$. On the basis of seismic tomography and residual gravity data, it has been suggested that the underlying lithosphere is abnormally cold and has dynamically subsided, possibly in conjunction with the subducting Nazca plate [Götze and Krause, 2002; Yuan et al., 2002; Schurr and Rietbrock, 2004].

[6] Although there have been several geological studies around the Salar de Atacama, its structure and tectonic setting are still not properly understood. Many authors have assumed that Cretaceous to Paleogene deposition occurred in an arc or back-arc setting, during a period of extensional tectonics [Hartley et al., 1992; Flint et al., 1993; Charrier and Reutter, 1994]. Other authors have suggested that the basin is due to compressional inversion of a Cretaceous rift basin [Macellari et al., 1991; Muñoz et al., 1997, 2002]. Development of the basin in the Oligocene to early Miocene has been attributed to a stage of relaxation, following late Eocene compressional tectonics [Götze and Krause, 2002]. In a recent paper, Pananont et al. [2004] have interpreted a seismic section across the northwestern edge of the basin, in such a way as to show that a large normal fault $(6 \pm 1 \mathrm{~km}$ of vertical separation) controlled the accumulation of Oligocene to lower Miocene strata. On this basis, the authors infer a period of localized extension. We have found no evidence for such extension at the surface, either there or anywhere else in the basin. Instead, we have found abundant evidence for shortening. Also, in our view, the evidence for normal faults on seismic sections is not convincing. However, we cannot rule them out. Thus the debate continues, as to the importance of extension in controlling the development of the Salar de Atacama basin in particular, and of the central Andes in general.

[7] Over the last few years, detailed mapping at the western edge of the Salar de Atacama basin [Arriagada, 1999; Arriagada et al., 2000, 2002; Mpodozis et al., 2005] has resulted in an improved knowledge of sedimentary strata at outcrop and their structural setting. Surrounding the basin are excellent exposures of Paleozoic to Tertiary strata and igneous rocks. In particular, a steep escarpment, $120 \mathrm{~km}$ long and $900 \mathrm{~m}$ high, forms the western margin of the basin. Here, the total stratigraphic thickness of outcropping Cretaceous to Paleogene rocks is almost $5 \mathrm{~km}$ (Figures $2 \mathrm{a}, 2 \mathrm{~b}$, and 3 ). Because these deposits contain growth strata, which accumulated during deformation, they provide a means of determining whether the tectonic context was one of horizontal extension, shortening, or strike slip, at least at the basin margin.

[8] In order to give our surface interpretations a more regional significance, we have compared them with a comprehensive set of two-dimensional (2-D) seismic reflection sections, covering much of the Salar de Atacama, and with data from an exploration well (Toconao-1), located in the center of the basin (Figures 2a, and 2b). Some of these data have been illustrated and discussed before [Macellari et al., 1991; Muñoz et al., 1997, 2002; Pananont et al., 2004]. In what follows we consider a wider range of individual seismic sections, composite sections, and fence diagrams, in 


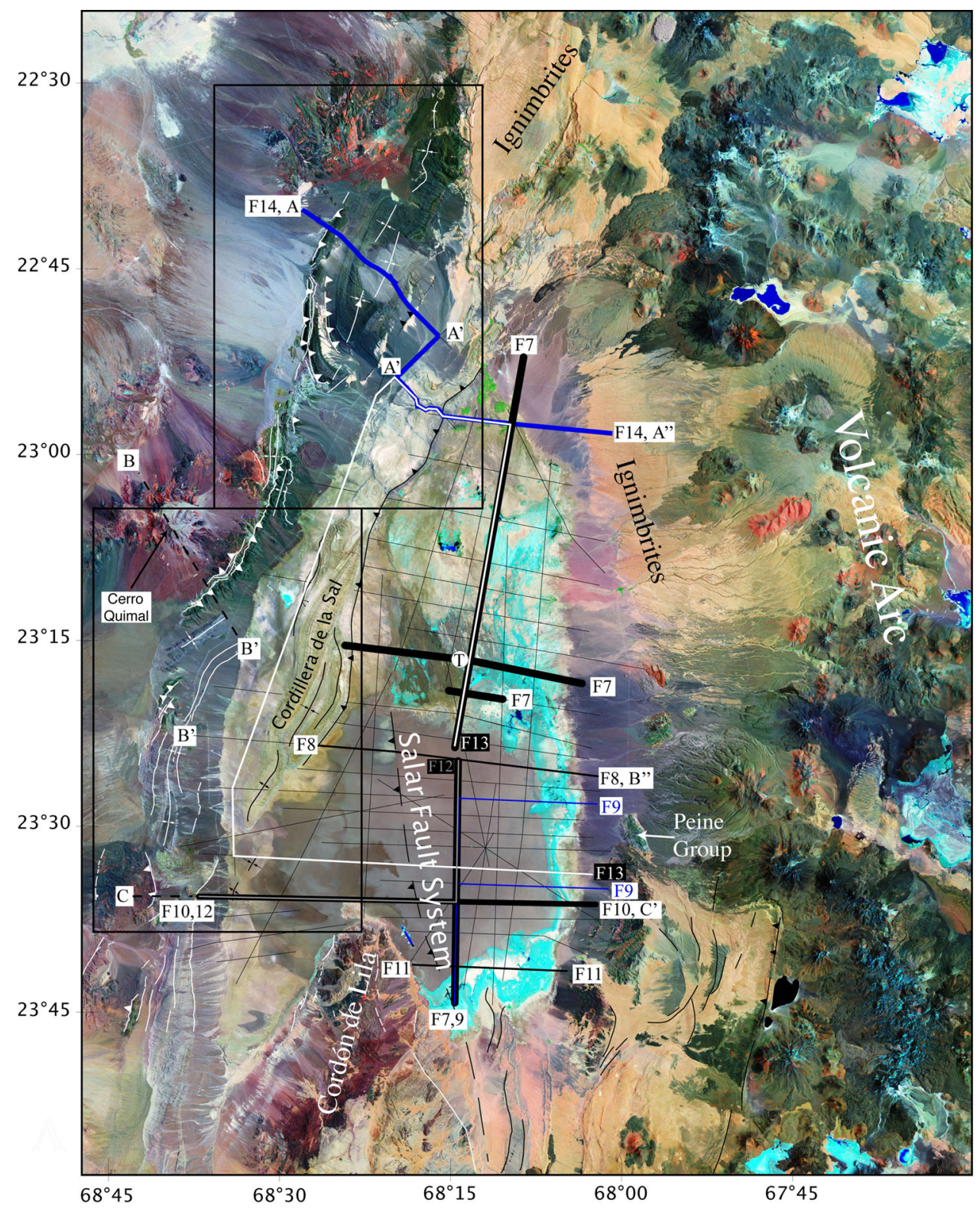

Figure 2a. Landsat image of Salar de Atacama basin, showing main topographic and geologic units, location of seismic lines available for this study, and position of Toconao-1 exploration well (full white circle in center of basin). Boxes show locations of Figures 3 and 4. F7-F14 indicate locations of seismic sections (Figures 7 to 14 ). A-A'-A', B-B'-B', and $C-C^{\prime}$ indicate locations of synthetic sections (Figure 15).

order to show how major reflectors may be traced across the basin. Such correlation is important for proper dating of sequences and for inferring the tectonic history of the basin.

\section{Geological Setting}

[9] The Salar de Atacama basin forms part of the presentday inner fore arc of northern Chile. At the western edge of the basin, the Cordillera de Domeyko (Precordillera) has an average altitude of $3000 \mathrm{~m}$ above sea level and is made of Paleozoic and Mesozoic rocks (Figures 1, Figures 2a, and 2b). The range went through a major period of uplift and erosion in the Eocene, probably as a result of the "Incaic" tectonic event [Ramírez and Gardeweg, 1982; Charrier and Reutter, 1994; Maksaev and Zentilli, 1999]. At its eastern edge, the Salar de Atacama rises gently toward the Western Cordillera, which is currently the main volcanic arc. On its slopes are Miocene and Pliocene ignimbrites and a few Late Paleozoic rocks (the Peine Group of Breitkreuz and Zeil [1994]). At its southern edge, the basin abuts the Western Cordillera (which here retreats some $60 \mathrm{~km}$ westward, adopting a NE-SW trend), and the Cordón de Lila range 


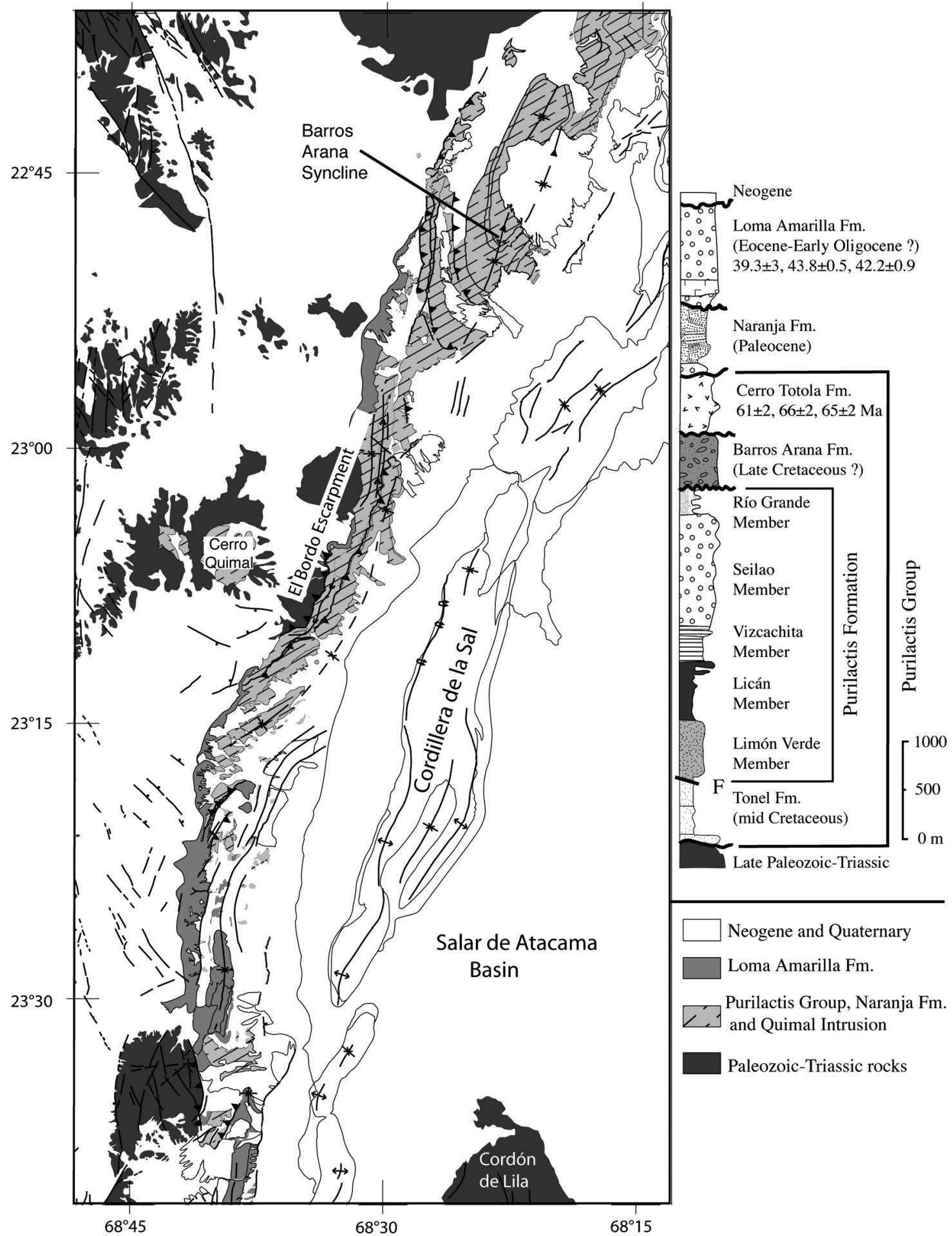

Figure 2b. Simplified geological map and stratigraphic column for western edge of Salar de Atacama basin.

(Figures 1, Figures 2a, and 2b), which comprises Ordovician to Carboniferous sedimentary and igneous rocks [Niemeyer, 1984; Damm et al., 1991]. Apatite fission track ages $(38.6 \pm 5.6 \mathrm{Ma})$ indicate that this basement was at a depth of 3-4 km during the late Eocene [Andriessen and Reutter, 1994].

[10] Cross cutting the basin near its western edge is the Cordillera de la Sal, a ridge $5-10 \mathrm{~km}$ wide that strikes 


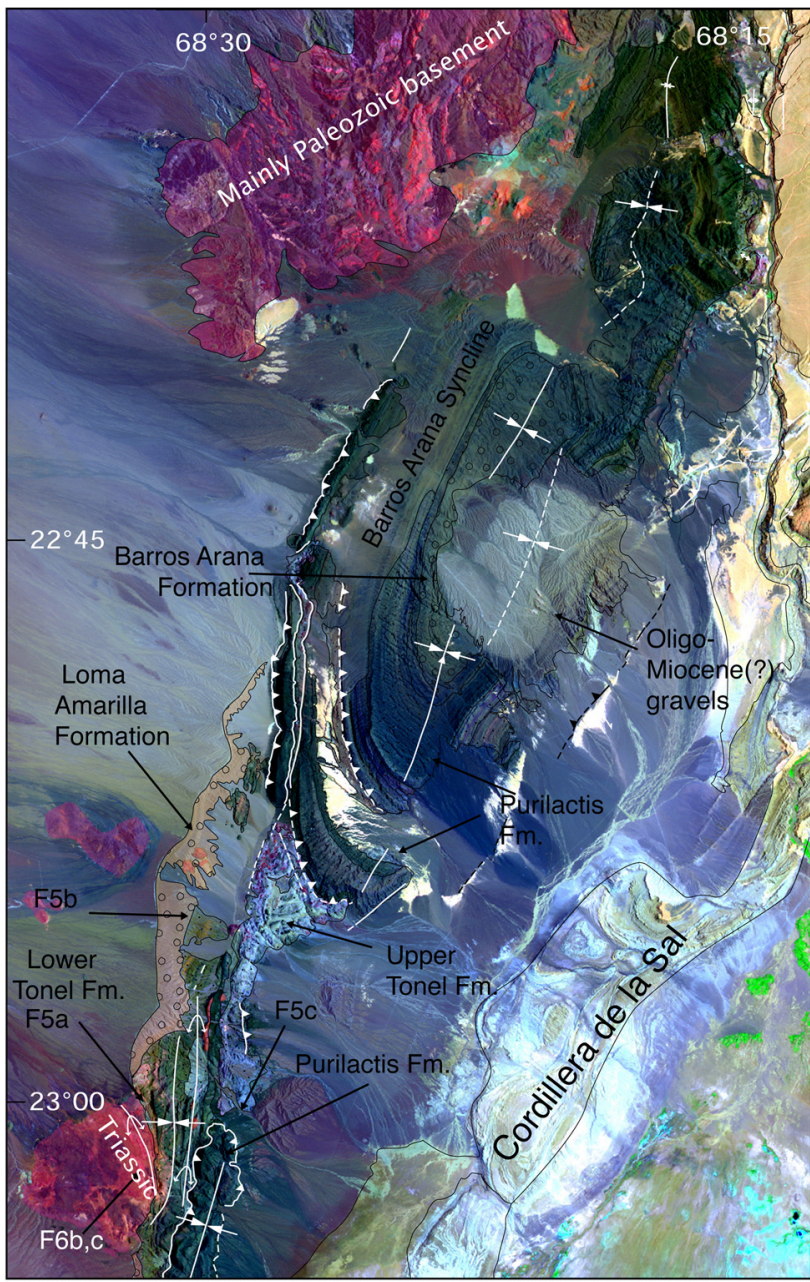

Figure 3. Geological map draped over Landsat image of northern El Bordo escarpment. For location, see Figure 1. F5a, F5b, F5c, F6b, and F6c indicate locations of photos in Figures 5 and 6.

SSW-NNE and rises some $200 \mathrm{~m}$ above the basin floor. Structurally, the ridge is a complex fold-and-thrust belt, which has uplifted Oligocene to Recent basin deposits, including evaporite-rich continental sediments and ignimbrites [Ramirez and Gardeweg, 1982; Flint et al., 1993; Wilkes and Görler, 1994]. The ridge separates the Salar de Atacama proper from the Llano de la Paciencia Figures $2 \mathrm{a}$ and $2 \mathrm{~b}$ ), which is a narrow subbasin, $80 \mathrm{~km}$ long and $8 \mathrm{~km}$ wide, containing Quaternary alluvial fans [Jolley et al., 1990].

[11] The eastern edge of the Cordillera de Domeyko is a topographic scarp, some $900 \mathrm{~m}$ high (El Bordo escarpment, Figures $2 \mathrm{a}$ and $2 \mathrm{~b}$ ), which extends for more than $120 \mathrm{~km}$ along the western margin of the basin. A series of major canyons has incised the escarpment, providing excellent exposures of the Mesozoic to Cenozoic basin fill, where it has been uplifted in a thrust belt (Figures 2a, 2b, 3, and 4). The total stratigraphic thickness of more than $5 \mathrm{~km}$ includes sedimentary and volcanic rocks of the Purilactis Group and of the Naranja and Loma Amarilla formations [Dingman,
1963; Ramírez and Gardeweg, 1982; Naranjo et al., 1994; Flint et al., 1993; Charrier and Reutter, 1994; Mpodozis et al., 2005]. To the east, these sequences continue in subsurface beneath the Llano de la Paciencia and the Atacama basin proper [Macellari et al., 1991; Muñoz et al., 1997, 2002].

\section{Stratigraphy at the Western Edge of the Salar de Atacama Basin}

[12] The older and best exposed sequences of the Mesozoic to Cenozoic Salar de Atacama basin fill crop out along a series of major E-W to NW-SE trending canyons, which cut across the El Bordo escarpment. Recent regional mapping (at 1:50.000 and 1:100.000) along the western edge of the basin [Arriagada, 1999; Mpodozis et al., 1999; Arriagada et al., 2000, 2002; Mpodozis et al., 2005] has resulted in an improved understanding of basin development. Here we briefly

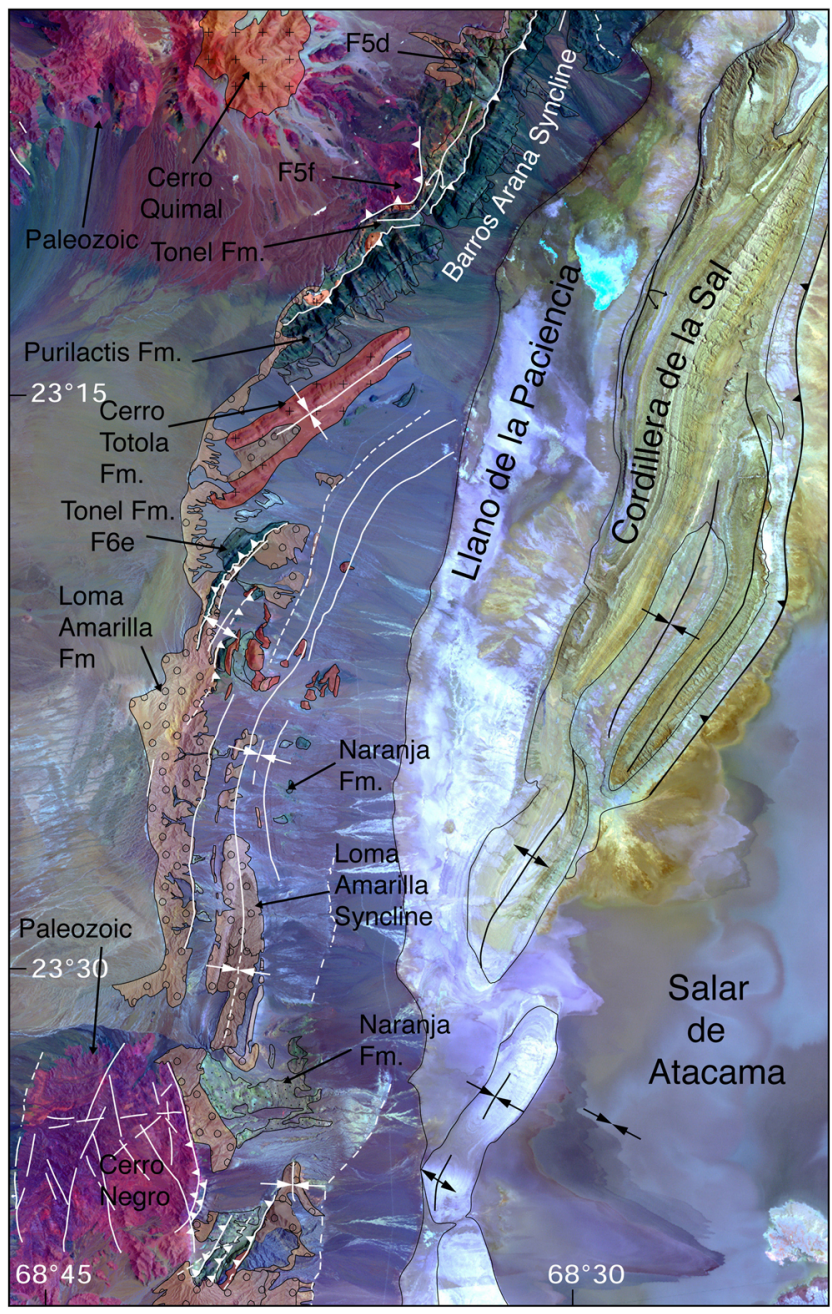

Figure 4. Geological map draped over Landsat image of southern El Bordo escarpment. For location, see Figure 1. F5d, F5f, and F6e indicate locations of photos in Figures 5 and 6. 

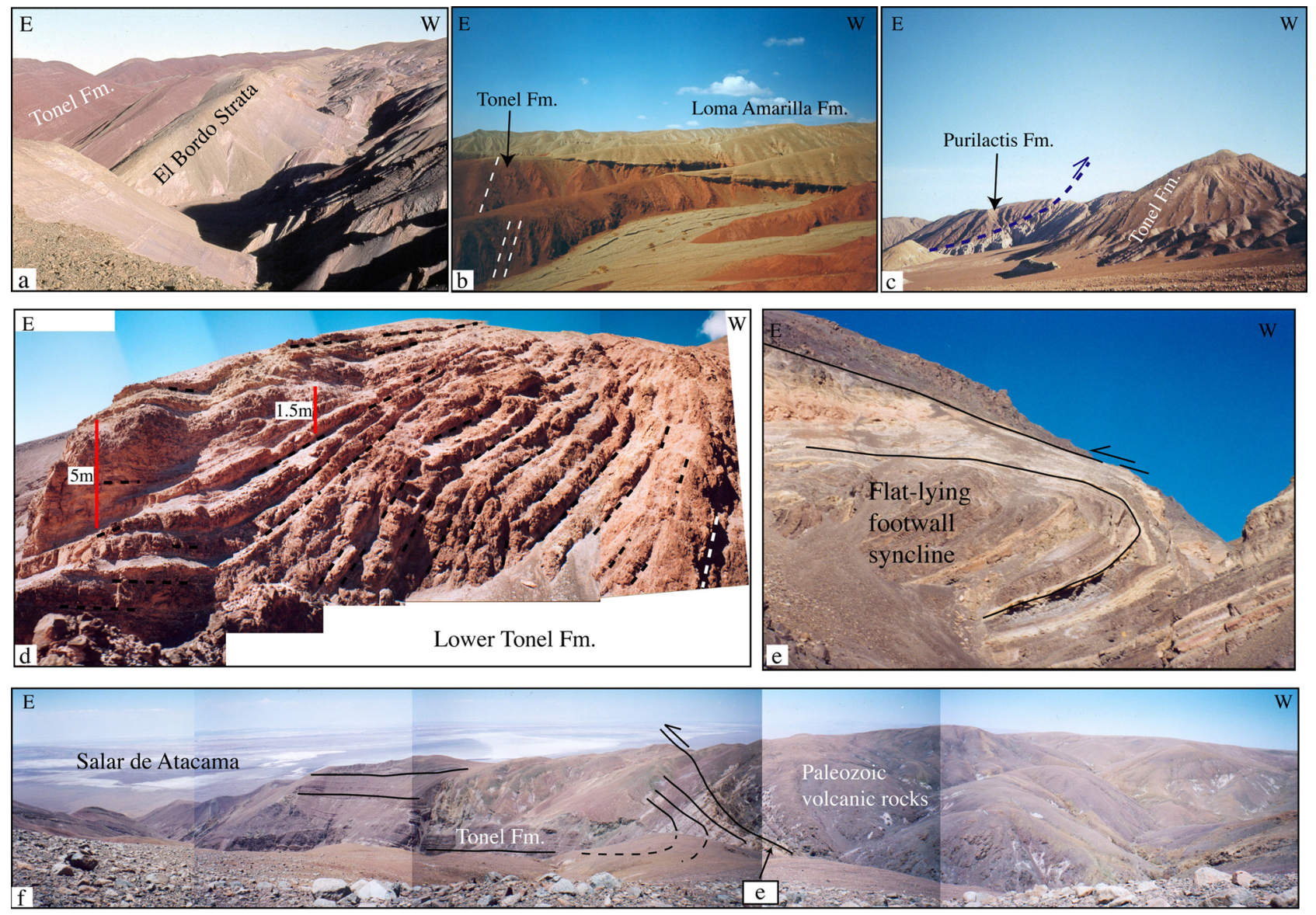

Figure 5. Structures at selected localities. For locations, see Figures 3 and 4. (a) Smooth angular unconformity between Tonel Formation and Triassic lacustrine sediments (El Bordo strata). (b) Large angular unconformity between Purilactis Group (red beds of Tonel Formation dipping at $70^{\circ}$ to $80^{\circ} \mathrm{E}$, white lines) and upper Loma Amarilla Formation (gently dipping to the west). (c) Purilactis Formation detached on evaporite beds of the Tonel Formation. (d) Growth strata in lower Tonel Formation [see also Mpodozis et al., 2005, Figure 6]. (e) Footwall syncline in lower Tonel Formation (see Figure 5f for location). (f) Thrust front at eastern edge of Cordillera de Domeyko.

describe the stratigraphy of the western edge, for better correlation with Toconao-1 well.

[13] At the base of the Purilactis Group, the Tonel Formation is a finely bedded sequence of red sandstones and evaporites, 400 to $1000 \mathrm{~m}$ thick, which accumulated in a continental playa-lake environment (Figures 2a, 2b, 3, 4, and 5). The Tonel Formation is slightly unconformable on Triassic lacustrine and volcanic rocks (Figures $5 \mathrm{a}$ and $5 \mathrm{~b}$ ), which in turn overlie late Paleozoic volcanic and intrusive rocks of the Cordillera de Domeyko.

[14] Overlying the Tonel Formation are almost $3000 \mathrm{~m}$ of fluvial, alluvial, and lacustrine red sandstones and mudstones of the Purilactis Formation (Figure 5c). Paleomagnetic data suggest that deposition and magnetization of the Tonel Formation and the lower part of the Purilactis Formation occurred during the mid-Cretaceous normal polarity superchron (119-84 Ma [Arriagada et al., 2000]).

[15] Overlying the Purilactis Formation, $500 \mathrm{~m}$ of alluvial fanglomerates of the Barros Arana Formation were depos- ited during Late Cretaceous time (Figure 3). Finally, $800 \mathrm{~m}$ of basaltic to rhyolitic lava flows with minor limestone beds of the Cerro Totola Formation form the upper part of the Purilactis Group. The Cerro Totola Formation is Late Cretaceous to early Paleocene (66 Ma to $61 \mathrm{Ma}$ ), according to $11 \mathrm{~K} / \mathrm{Ar}$ ages on lava flows and related intrusions, including the Cerro Quimal pluton [Mpodozis et al., 2005]. A strong angular unconformity separates the Purilactis Group from the overlying Naranja and Loma Amarilla formations (Figures 2a, 2b, 3, 4, and 5b).

[16] The Naranja Formation consists of $900 \mathrm{~m}$ of conglomerate, passing up into sandstone and evaporite beds. Overlying them are a tuff layer and up to $1000 \mathrm{~m}$ of coarse conglomerate of the Loma Amarilla Formation. A volcanic rock at the base of the Loma Amarilla Formation has yielded late Eocene ages, both by $\mathrm{K} / \mathrm{Ar}$ on plagioclase $(39.9 \pm 3 \mathrm{Ma}$ [Ramírez and Gardeweg, 1982]) and by ${ }^{40} \mathrm{Ar}{ }^{39} \mathrm{Ar}$ plateau ages on biotite $(43.8 \pm$ 0.5 and $42.2 \pm 0.9$ [Hammerschmidt et al., 1992]). The upper part of the sequence, poorly dated, probably 

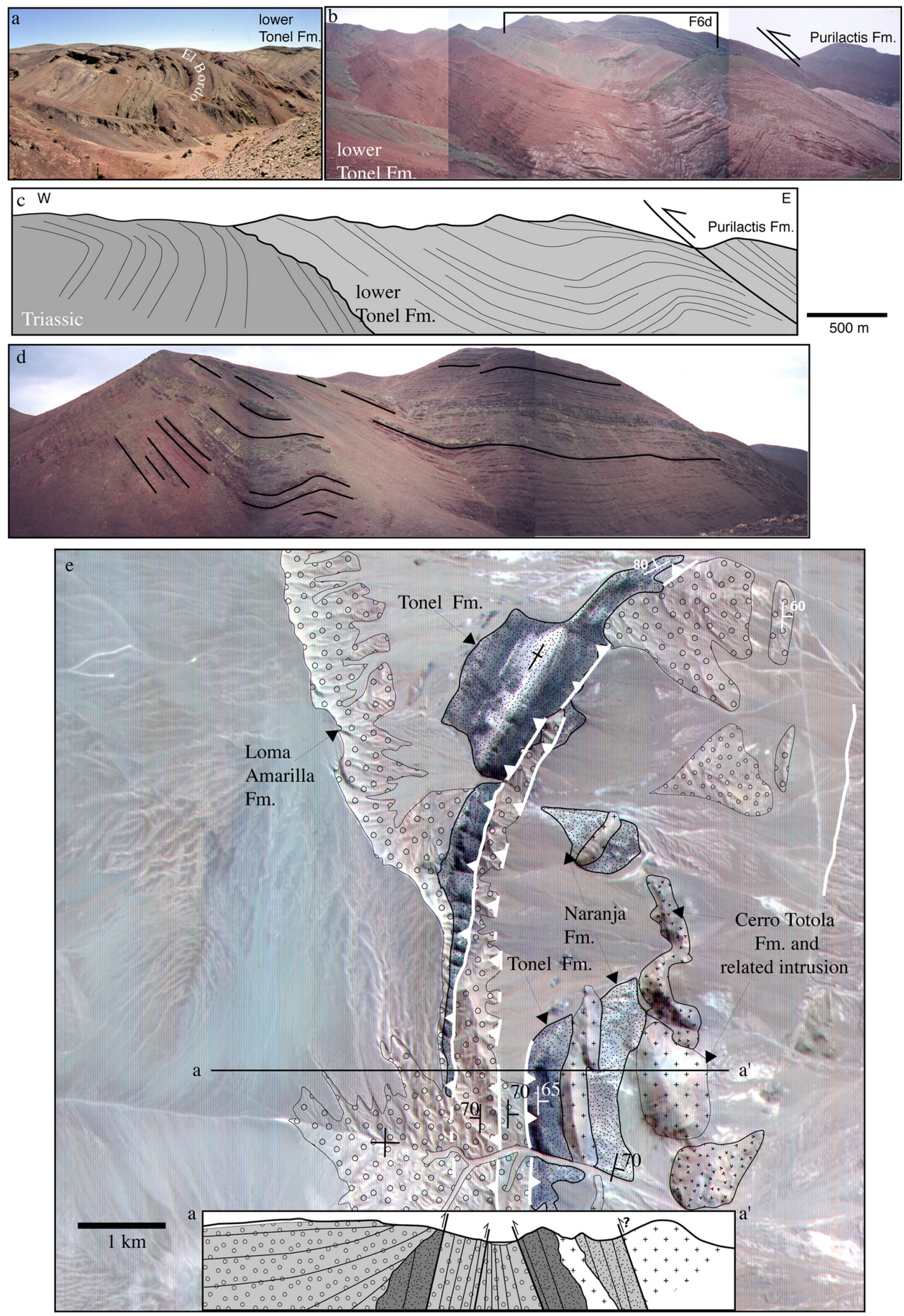

Figure 6. Evidence for compressional setting during sedimentation. (a) Growth anticline overturned to east in Triassic El Bordo strata and lower Tonel Formation. (b) Growth syncline in red beds of lower Tonel Formation. (c) Line drawing of Figures 6a and 6b. (d) Enlargement of Figure 6b. Deeper strata form a syncline, whereas shallower strata do not. (e) Geological map draped on ASTER image and E-W section of transition zone between Barros Arana and Loma Amarilla synclines (see Figure 4). 
accumulated during early Oligocene time [Mpodozis et al., 2005].

\section{Surface Structure at the Western Edge of the Salar de Atacama Basin}

[17] In the northwestern corner of the basin, the most prominent feature is the large open Barros Arana syncline (Figure 3). On its western limb, a westward verging back thrust has detached the Purilactis Formation (in the hanging wall) from evaporites of the Tonel Formation (in the footwall). The back thrust can be traced all along the El Bordo escarpment (Figures 2a, 2b, 3, 4, and 5c). In the central part of the area (Cerro Quimal), the syncline becomes tighter, adopting a chevron style, and its axial plane dips westward (Figures 2a, 2b, and 4). The axial trace curves, from $\mathrm{N} 20^{\circ} \mathrm{E}$ at Barros Arana, through $\mathrm{N} 60^{\circ} \mathrm{E}$ at Cerro Totola. In the footwall of the detachment between Purilactis and Tonel formations is an anticline, overturned to the east. This appears to be a fault propagation fold above an eastward verging thrust, which roots into the eastern edge of Cordillera Domeyko (Figures 4 and 6). About $1 \mathrm{~km}$ to the SE, a syncline and adjacent anticline mark the lower part of the Tonel Formation, whereas no folds are visible in its upper part (Figures 4 and 6). Another $5 \mathrm{~km}$ to the $\mathrm{S}$, the basal section of the Tonel Formation contains growth strata (Figure 5d). These were deposited on pregrowth strata, which form kink folds. On the southeastern side of Cerro Quimal, Late Paleozoic (and early Triassic?) volcanic rocks overthrust the Tonel Formation above an eastward verging footwall syncline (Figures 4 and 5f).

[18] To the south of Cerro Totola, the Barros Arana syncline disappears and a complex zone of deformation replaces it. Further south is the conspicuous Loma Amarilla syncline. In contrast to the Barros Arana syncline, which contains the Purilactis Group, the Loma Amarilla syncline contains Paleocene to Eocene deposits of the Naranja and Loma Amarilla formations (Figures 4 and 6e). In the deformation zone between the two synclines, the Naranja and Loma Amarilla formations are overthrust by red beds of the Tonel Formation on the eastern limb of the Barros Arana syncline (Figures 4 and 6e). Growth strata in conglomerate of the Loma Amarilla Formation argue for syntectonic sedimentation during uplift of the Cordillera de Domeyko and eastward thrusting of the Barros Arana Syncline over the Paleocene to Eocene (and Oligocene?) strata (Figures 4 and 6e). Reverse faults also offset Quaternary gravels, indicating that compressional deformation is still active (Figure 6e). Farther south, around Cerro Negro, evaporitic facies of the upper Naranja and upper Loma Amarilla formations are intensely deformed in the footwall of an eastward verging thrust that brings the basement to outcrop. The Loma Amarilla Formation is steeply dipping to vertical at outcrop, for several $\mathrm{km}$ to the south of Cerro Negro.

[19] Nowhere at the surface have we found normal faults of any significance, other than small ones that may have formed as a result of slope instability. Steep faults, trending $\mathrm{N}-\mathrm{S}$ and carrying right-lateral gently dipping striations, are relatively common at outcrop, but we have no constraints on their timing. Thus, on the basis of surface mapping alone, we would infer that the Salar de Atacama basin has developed in a compressional or transpressional setting, continuously or intermittently, since the mid-Cretaceous.

\section{Subsurface Structure of the Basin}

\subsection{Stratigraphic Correlation of EI Bordo Escarpment and Toconao-1 Well}

[20] Muñoz et al. [1997, 2002] and Pananont et al. [2004] have published accounts of the strata encountered in the center of the basin by the Toconao-1 exploration well. Here we attempt to correlate the well record with the surface outcrops along the El Bordo escarpment.

[21] The Toconao-1 well reached a total depth of about $5500 \mathrm{~m}$ (Figures 2a, 2b, and 7). Between 2895 and $3900 \mathrm{~m}$, a well-defined seismic unit consists of sandstone, marine limestone, anhydrite and claystone beds, which formed in a marine setting [Muñoz et al., 1997, 2002]. These marine facies of the Toconao-1 well have been correlated with the Yacoraite Formation, which is well exposed in the Puna and Eastern Cordillera of Argentina, but is not known to the west of Cordillera Domeyko. Maastrichtian fauna of the Yacoraite Formation are of Atlantic affinity, due to a marine transgression, which occurred in Late Cretaceous to Paleocene time [Salfity, 1985; Galliski and Viramonte, 1988; Marquillas and Salfity, 1994]. These deposits and the volcanic rocks of the Cerro Totola Formation have similar age ranges. Although other names have been used for units in the Toconao-1 well [Muñoz et al., 1997, 2002; Jordan et al., 2002; Pananont et al., 2004], for simplicity we adopt those from the El Bordo escarpment. Thus we correlate the Late Cretaceous intervals of Toconao- 1 well with the Cerro Totola Formation (Figure 7).

[22] Beneath the Cerro Totola Formation, the Toconao-1 well encountered $1500 \mathrm{~m}$ of sandstone, siltstone and limestone, interbedded with volcanic rocks. This sequence has been described as basement (Peine Group). However, there are no precise ages for it. Moreover, on the seismic data no unconformity is visible between the Late Cretaceous sequence and any underlying Paleozoic basement. We consider that the lower section of the Toconao-1 well (labeled Cerro Totola Formation in Figure 7) may be at least partly equivalent to the Cerro Totola Formation (or lower units of the Purilactis Group). However, the quality of the seismic data is insufficient at this depth for proper correlation with the western edge of the basin. Therefore we do not know if other facies of the Purilactis Group continue across the Salar de Atacama.

[23] What we have identified as Cerro Totola Formation in the Toconao-1 well is unconformably overlain by about $800 \mathrm{~m}$ of volcaniclastic sandstone and conglomerate. The top of this sequence can be traced as far as the western edge of the basin, where it coincides with the top of the Naranja Formation (see below). In the well, this unit is unconformably overlain by of a continental coarsening upward sequence, about $500 \mathrm{~m}$ thick, which consists of sandstone and numerous interbeds of claystone, volcanic conglomerate and minor sandstone [Muñoz et al., 2002]. This unit 


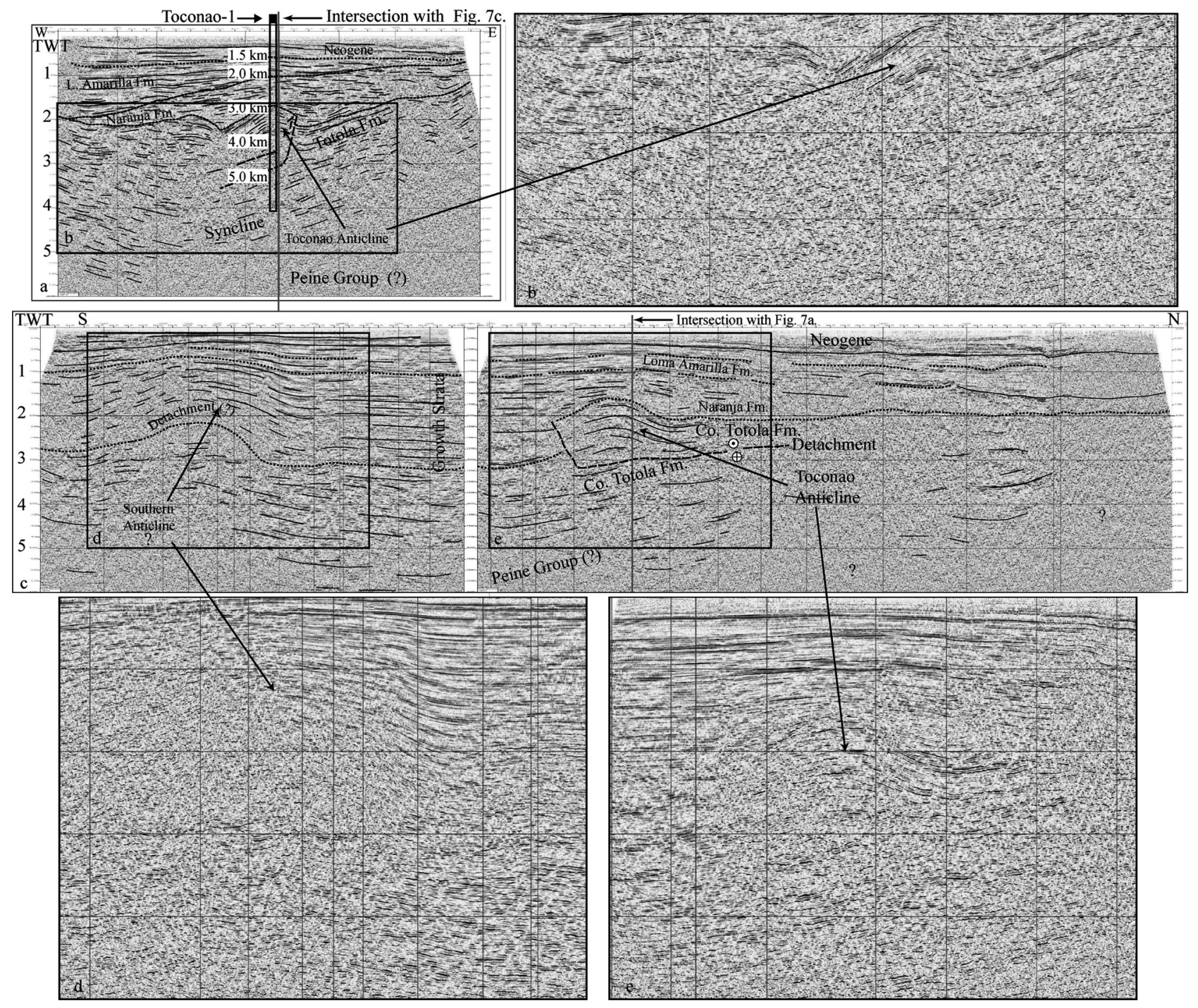

Figure 7. Seismic section of Salar de Atacama basin (see Figure 2a for location). Vertical scales are in seconds of two-way traveltime (TWT). (a) E-W section through Toconao-1 well (column with depth in $\mathrm{km}$.). Box locates enlargement in Figure 7b. (b) Enlargement of E-W section (Figure 7a), showing Toconao anticline. (c) N-S section through Toconao-1 well. Boxes locate enlargements in Figures 7d and 7e. (d) Enlargement of N-S section (Figure 7c), showing southern anticline. (e) Enlargement of N-S section (Figure 7c), showing northern (Toconao) anticline. In Figures 7a and 7c, dotted lines follow main stratigraphic boundaries, and grey vertical lines mark intersection of N-S and E-W sections. Detachments (dashed lines) have been inferred under both anticlines (Figures 7a and 7c). Note domical geometry of Toconao anticline (Figures 7a and 7c), related growth strata in Naranja and Loma Amarilla formations, detachment in Cerro Totola Formation, and underlying syncline (Figures $7 \mathrm{a}$ and $7 \mathrm{c}$ ).

may be a distal equivalent of the Eocene to Oligocene Loma Amarilla Formation. Neogene to Recent continental deposits, mainly of claystone, sandstone, evaporites and interbedded ignimbrite, complete the basin fill [Muñoz et al., 1997, 2002; Jordan et al., 2002; Pananont et al., 2004].

\subsection{Seismic Database and Interpretation}

[24] Empresa Nacional de Petróleos (ENAP) made available to us in digital form a set of regional 2-D seismic reflection sections, covering much of the Salar de Atacama
(Figures $2 \mathrm{a}$ and $2 \mathrm{~b}$ ). This database is essentially the same as the one available to Pananont et al. [2004]. However, in contrast to Pananont et al. [2004], we did not process any of the data ourselves. As received, the seismic sections were already time-migrated, but not depth-converted. Thus the vertical scale is in seconds of two-way traveltime (TWT), rather than true depth. The Toconao-1 well provides the only reliable control on true depth and this is valid locally. Thus, in the seismic sections that follow, the main vertical scale is in time, although an approximate scale in $\mathrm{km}$ also figures. 

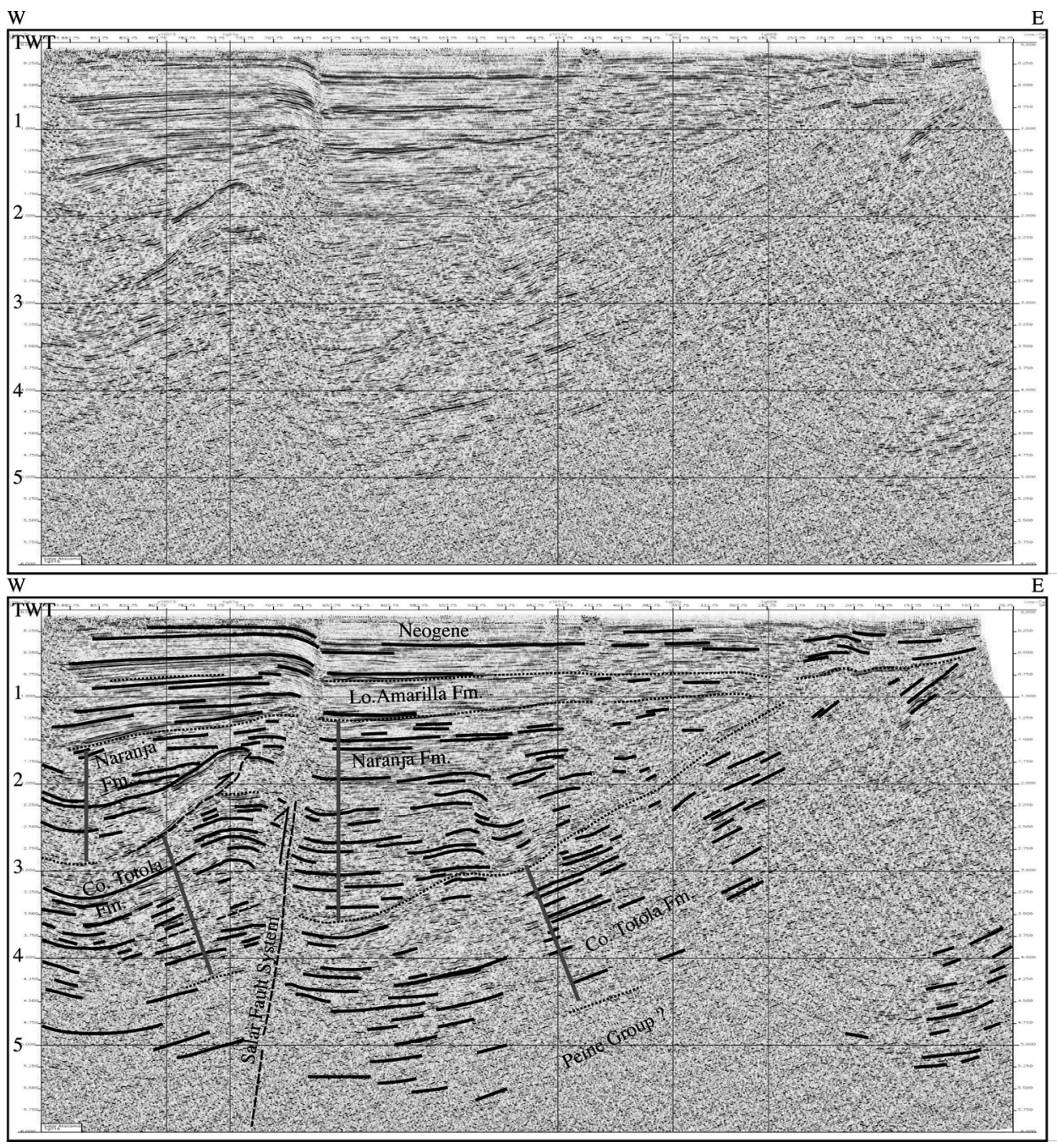

Figure 8. (top) E-W seismic section to south of Toconao anticline (see Figures $2 \mathrm{a}$ and $2 \mathrm{~b}$ for location). Vertical scales are in seconds of two-way traveltime (TWT). (bottom) Interpreted version. Black bars perpendicular to bedding in Cerro Totola Formation are of equal lengths and show that beds do not vary in thickness across Salar Fault System, whereas black bars in Naranja Formation shows large variations in thickness across fault. Growth strata in Naranja Formation are best seen in footwall of Salar Fault System, whereas hanging wall sequence is more condensed. Note progressive unconformities in Naranja Formation, above hanging wall of Salar Fault System.

[25] In all examples, for clarity of interpretation, we show both noninterpreted and interpreted sections. Interpretation involved identifying seismic reflections and following them where possible along each section, from one section to the next, and as far as neighboring outcrops, to form a self-consistent set. Growth strata and progressive unconformities, especially next to folds and faults, were the main features that we took as evidence for synsedimentary deformation.

\subsection{Subsurface Structure to the East of the Cordillera de la Sal}

[26] According to our seismic interpretation, the main structural features to the east of the Cordillera de la Sal are a high-angle eastward verging reverse fault (the Salar Fault System of Muñoz et al. [2002] (Figures 2a and 2b)) and two anticlines on its eastern side (Figures $7 \mathrm{a}$ and $7 \mathrm{c}$ ). The northern Toconao anticline is domical (doubly plunging) and the Toconao-1 exploration well targeted a four-way anticlinal closure (Figures 7a and 7c). The anticline is in the hanging wall of an eastward verging thrust, which detaches within the Cerro Totola Formation. To the south, the anticline terminates against a right-lateral ramp (Figures $7 \mathrm{c}$ and 7e). Muñoz et al. [1997, 2002] have suggested that the Toconao anticline has resulted from compressional reactivation of an extensional fault, which roots into basement. According to their interpretation, displacement on the fault was of normal (extensional) sense during accumulation of the Cerro Totola Formation. Despite the poor quality of the 


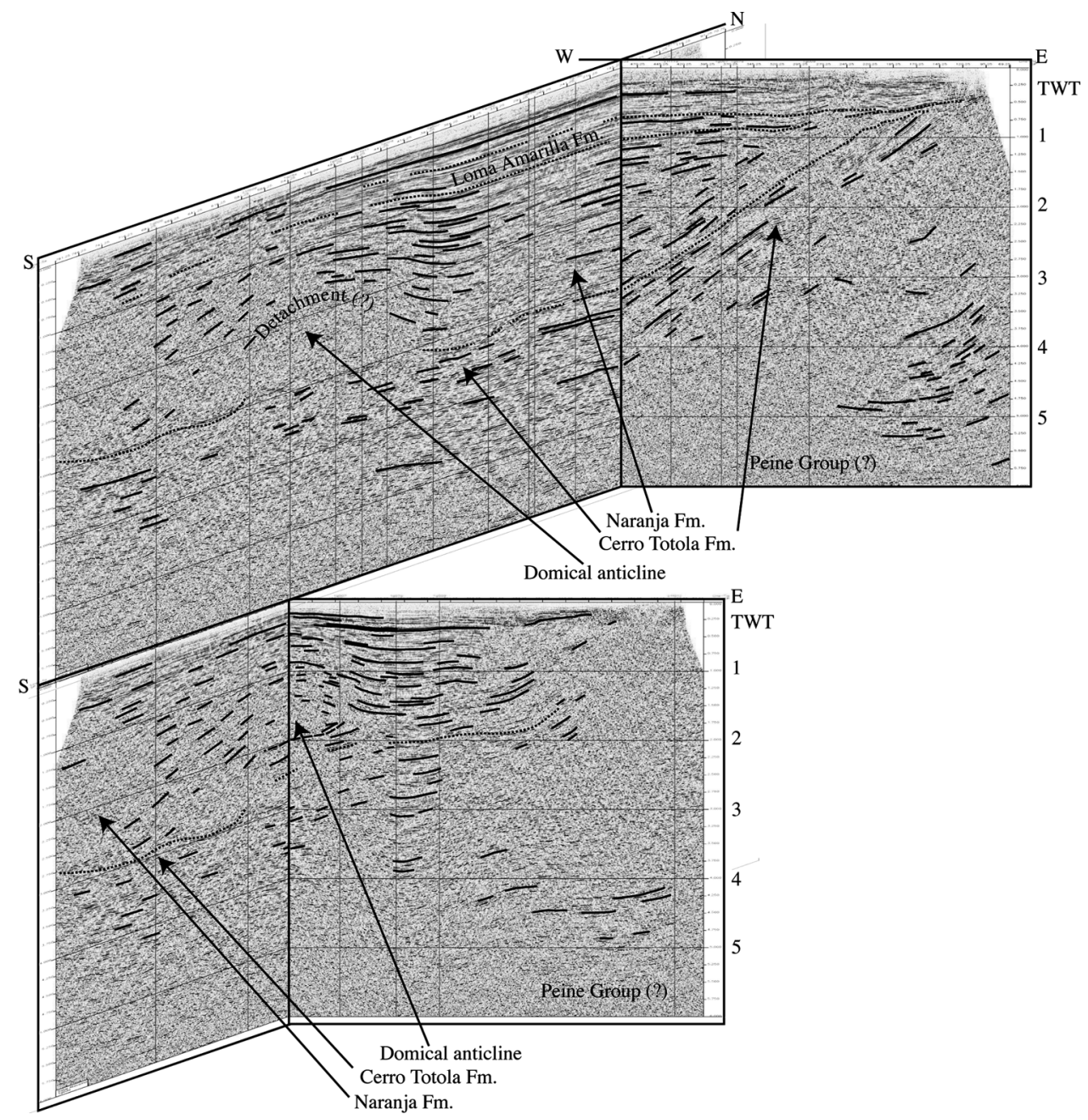

Figure 9. Fence diagram for northern anticline to east of Cordón de Lila, showing N-S variation in structural style (see Figures $2 \mathrm{a}$ and $2 \mathrm{~b}$ for location). Vertical scales are in seconds of two-way traveltime (TWT).

seismic data between 3 and 6 seconds of two-way traveltime (TWT, Figures 7a and 7c), in other words around $5 \mathrm{~km}$ depth in Toconao 1 well (Figure 7a), the Toconao anticline and its detachment appear to be underlain by a syncline. The lateral ramp does not offset the Peine Group and we see no evidence of thickness variations in strata of the Cerro Totola Formation (Figures 7c and 7e). Thus we argue that the Toconao anticline is thin-skinned and postdates the Cerro Totola Formation.

[27] Between the two anticlines, a large depocenter lies next to the Salar Fault System (Figures 7c and 8). In its hanging wall, the Cerro Totola Formation forms an anticline-syncline pair (Figure 8). The Salar Fault System clearly offsets the anticline. Whereas the thickness of the Cerro Totola Formation is invariant across the fault and folds, Paleogene and Neogene strata show large variations in thickness. In the footwall of the Salar Fault System, the Naranja Formation occupies a major depocenter, whereas in the hanging wall it forms a more condensed sequence. Here, stratigraphic onlap and progressive unconformities are visible above an eastward verging thin-skinned detachment in the Cerro Totola Formation (Figures 7 and 8). Thus there is good evidence here for an episode of Paleocene to Eocene shortening and thickening.

[28] The southern anticline (Figures $7 \mathrm{c}$ and $7 \mathrm{~d}$ ) lies to the east of the Cordon de Lila basement range. Again, it is domical. The maximal fold amplitudes are in the Naranja Formation, which also shows large variations in thickness across the anticline (Figures 7c, 8, and 9). The Cerro Totola Formation can be traced all along a N-S seismic section and is flat-lying under the anticline. Thus, whereas the more northern Toconao anticline has maximal amplitudes in the Cerro Totola Formation, the southern anticline is visible in the Naranja and Loma Amarilla formations, but not in the Cerro Totola Formation. We infer a detachment between the Naranja and Cerro Totola formations.

[29] A seismic section near the southern edge of the basin reveals a wedge of seismically more transparent basement of the Cordón de Lila range, between two 


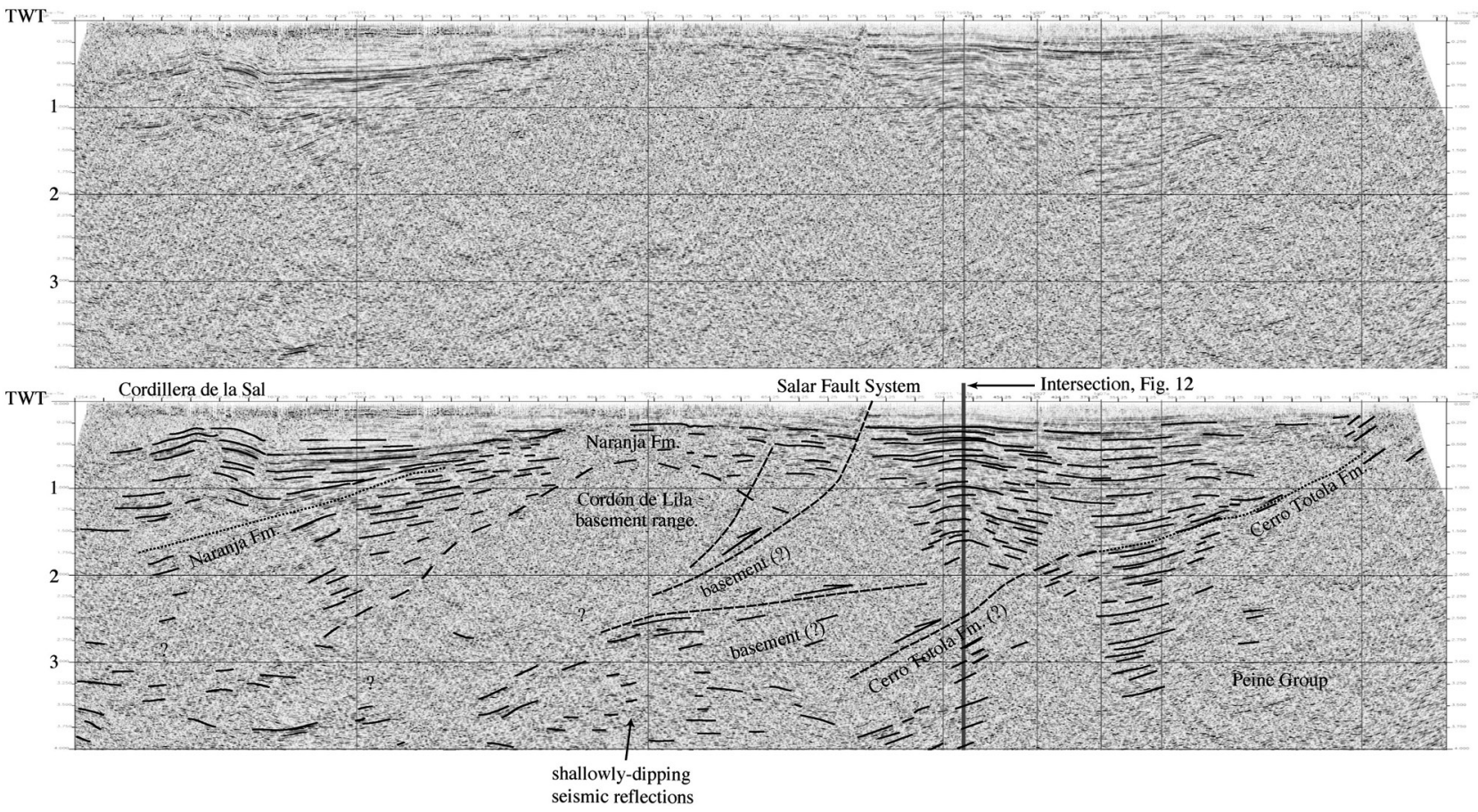

Figure 10. E-W seismic section near southern edge of Salar de Atacama basin. Vertical scales are in seconds of two-way traveltime (TWT). For location, see Figures 2a and 2b. Cordón de Lila basement appears to overthrust Cerro Totola Formation.

subbasins (Figure 10). At the eastern edge of the basement is the Salar Fault System. The displacement on it is smaller than in the central area (compare Figures 8 and 10). However, in its footwall there may be as many as three imbricate eastward verging thrust sheets. Across two of them, the Neogene sequences have characteristic growth strata (Figure 11). At outcrop, detailed structural mapping has revealed an eastward verging thin-skinned fold-andthrust belt in strata of Oligocene to Pleistocene age [Ramírez and Gardeweg, 1982; Kuhn, 2002].

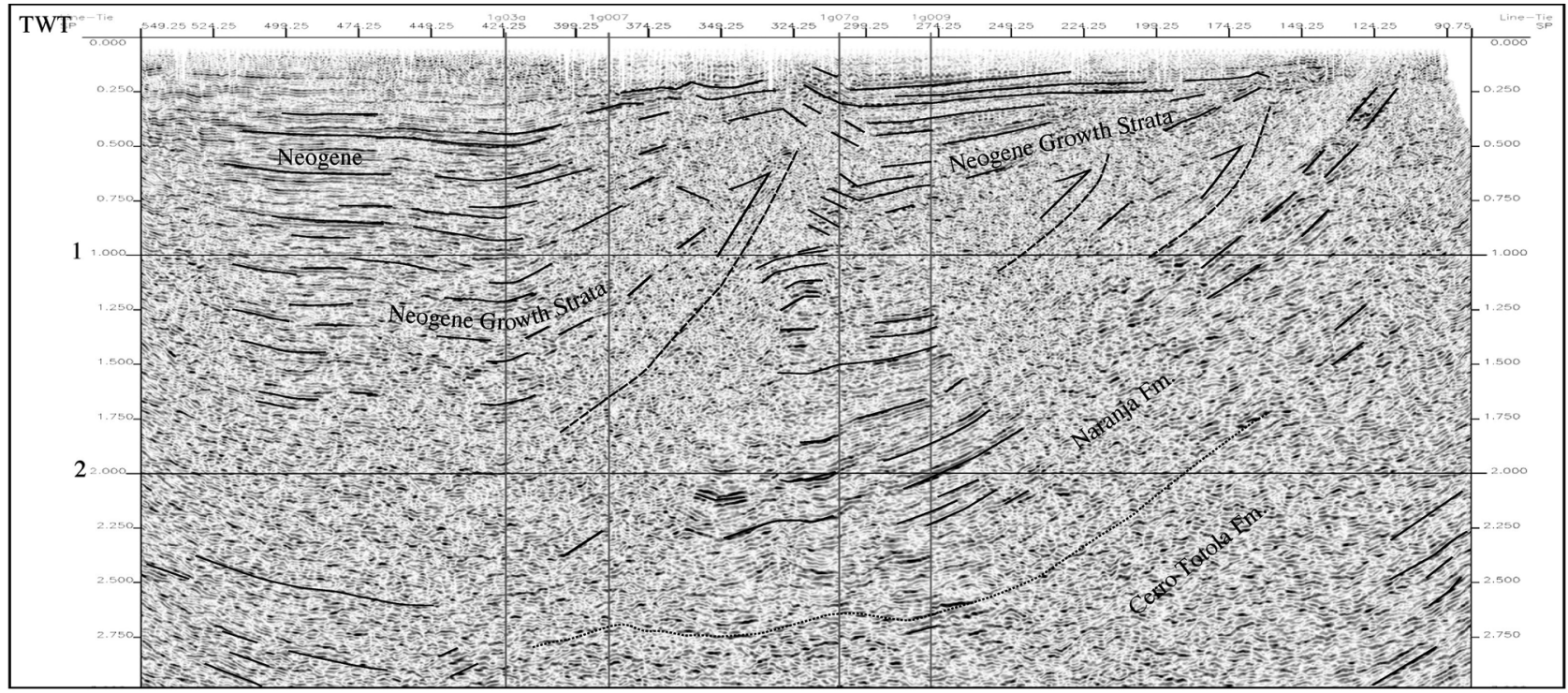

Figure 11. E-W seismic section at southeastern edge of Salar de Atacama basin. Vertical scale is in seconds of two-way traveltime (TWT). For location, see Figures $2 \mathrm{a}$ and $2 \mathrm{~b}$. At least three eastward verging imbricate sheets account for Neogene to recent compressional tectonics. Detachment is in Naranja Formation. 


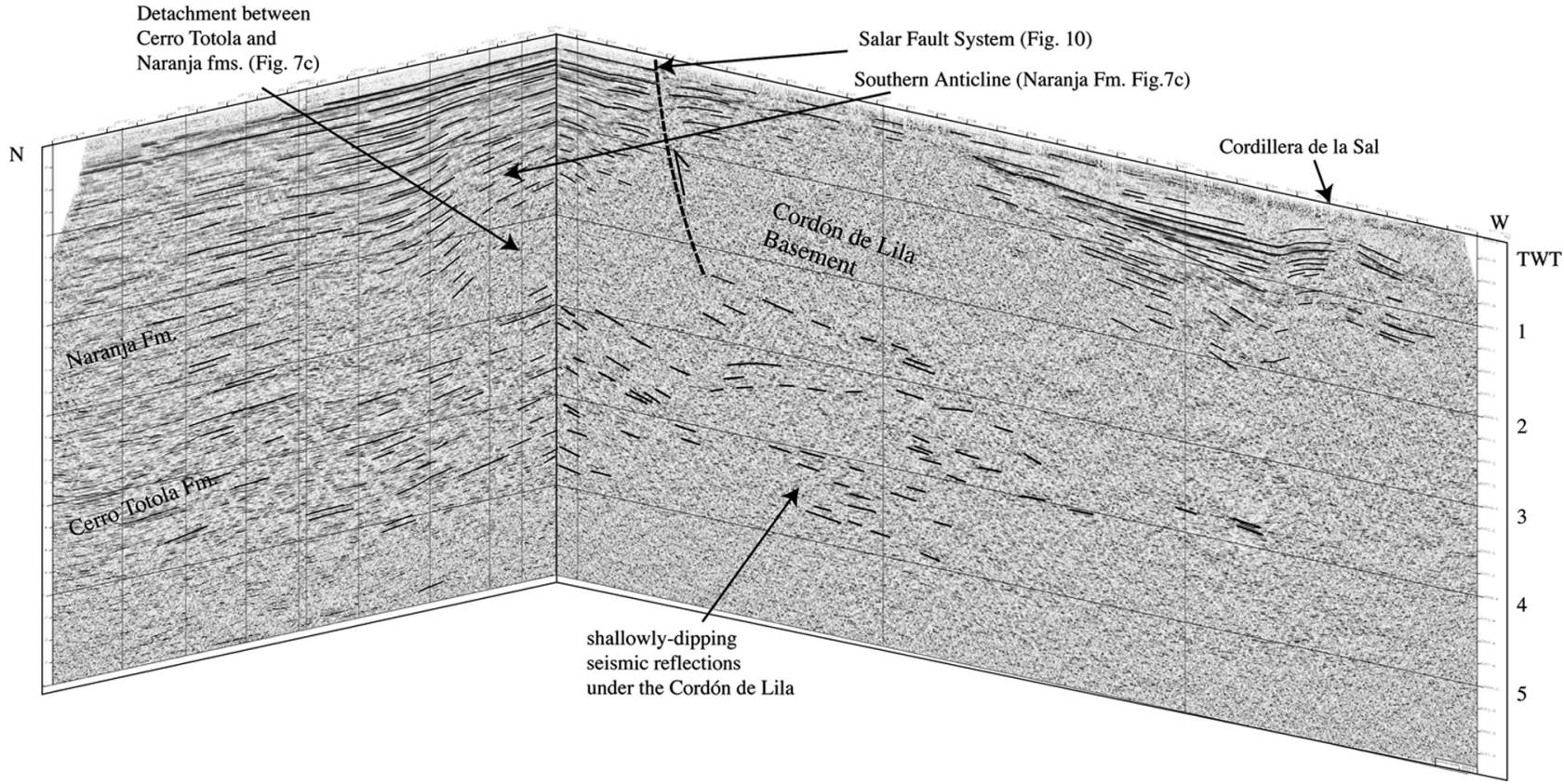

Figure 12. Block diagram, showing reflectors that appear to continue under Cordón de Lila basement. Vertical scales are in seconds of two-way traveltime (TWT). Block is at intersection of N-S (Figure 7c) and E-W (Figure 10) sections. For location, see Figures $2 \mathrm{a}$ and $2 \mathrm{~b}$.

[30] Despite the poor quality of the seismic data (Figure 10), gently dipping seismic reflections can be traced under the Cordón de Lila (Figure 12). Even though the shapes of reflection events probably reflect some velocity pull-up, due to shorter traveltimes through basement rocks of higher velocity, the Cerro Totola Formation and the Peine Group appear to be overthrust by the Cordón de Lila basement. If our interpretation is correct, horizontal short- ening is more significant and deep seated than previously thought.

\subsection{Subsurface Structure to the West of the Cordillera de la Sal}

[31] Muñoz et al. [1997, 2002] have indicated that the fold-and-thrust belt of the Cordillera de la Sal, in the

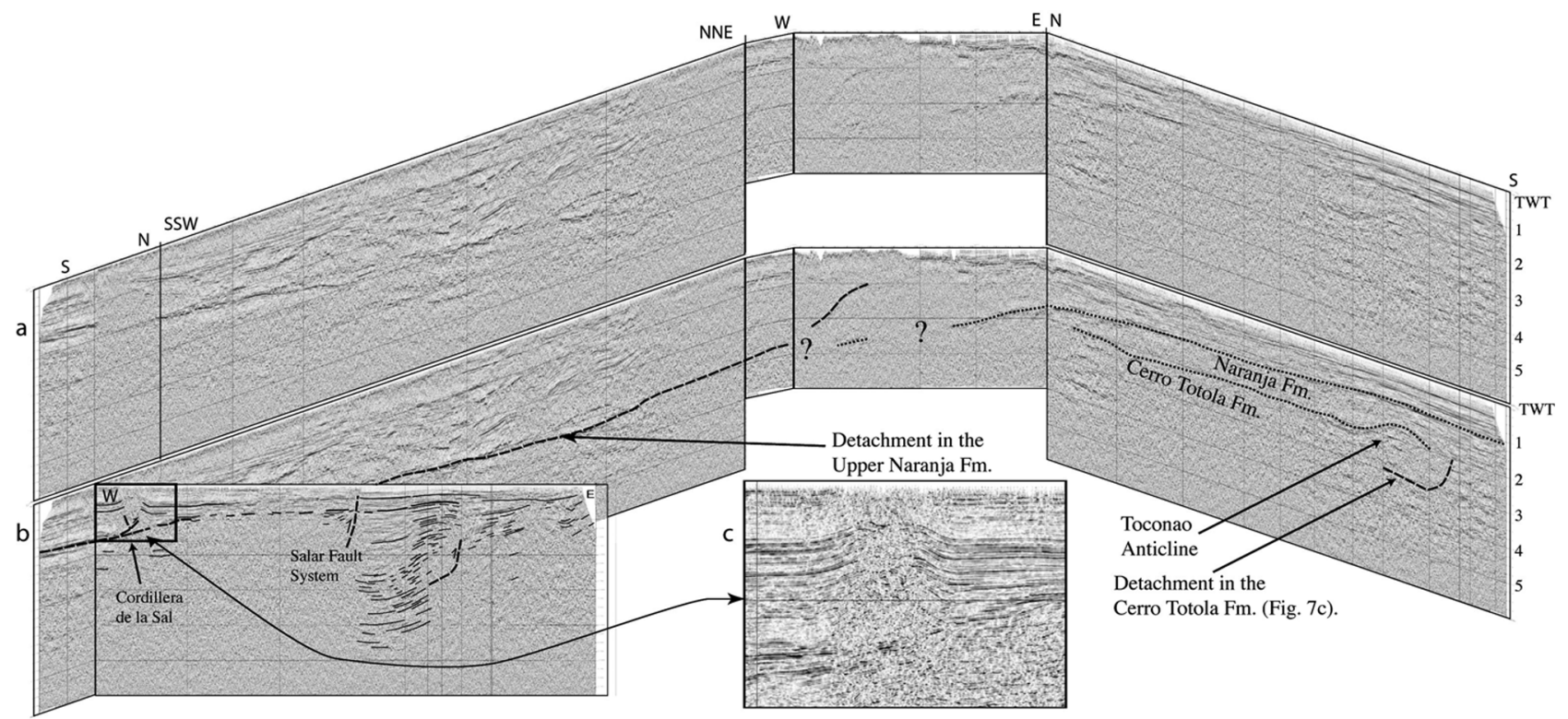

Figure 13. (a) Composite seismic section (U-shaped, perspective view), showing depth to detachment at top of Naranja Formation. (b) Interpreted version of Figure 13a. (c) Enlargement of box in Figure 13b. For location of sections, see Figures 2a and 2b. 


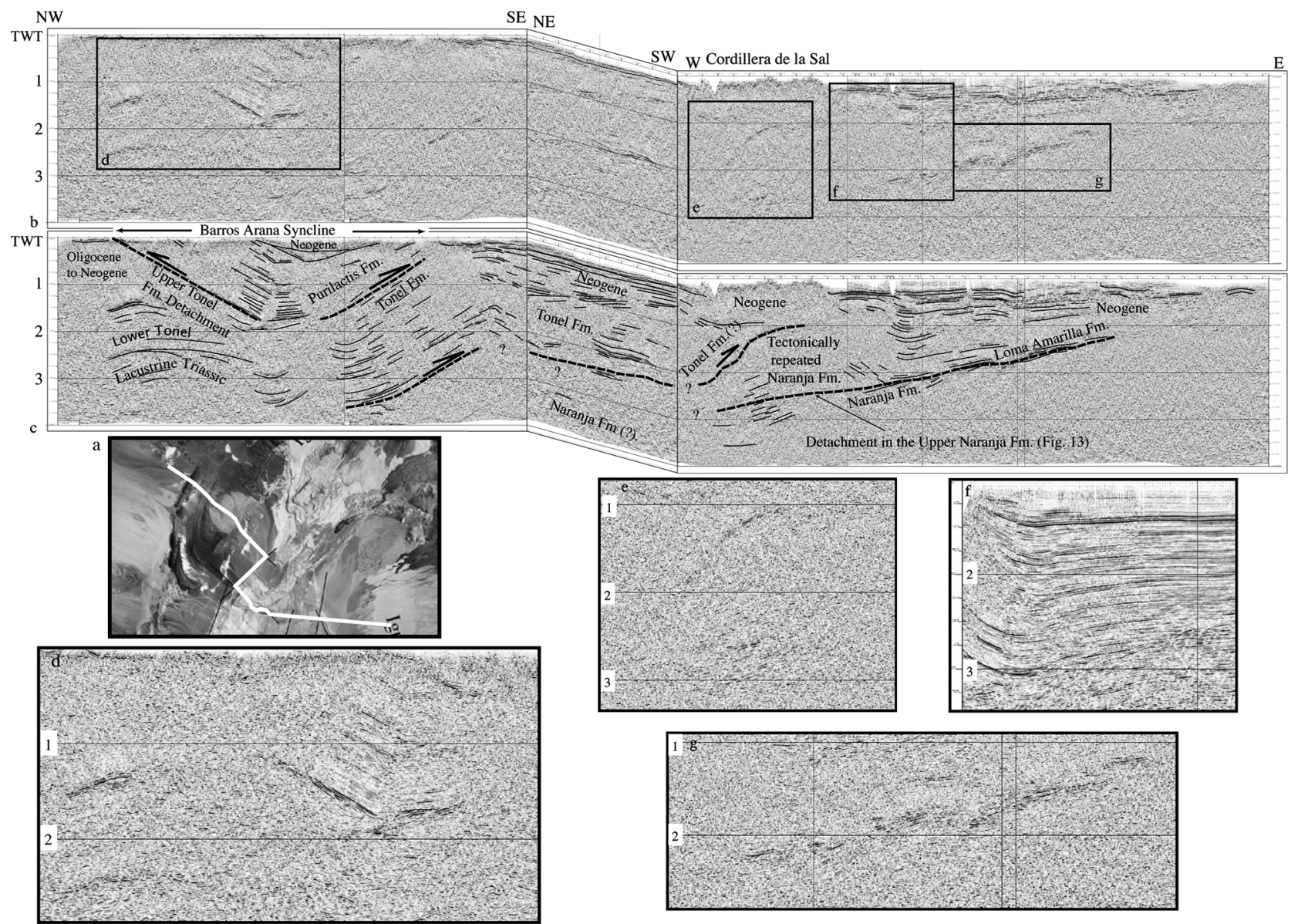

Figure 14. Composite seismic section of Barros Arana syncline. (a) Location of seismic sections. (b) Raw data. (c) Interpreted section showing Purilactis Group (and perhaps lacustrine Triassic strata) thrust eastward over Paleogene and Neogene sequences (see text for details). Identified reflectors are also shown in Figures 13a and 13b. (d, e, and g) Enlargements are of boxes in Figure 14b. (f) Enlargement of deformation at eastern edge of Cordillera de la Sal taken from another seismic section, parallel to this one, but several kilometers to the south. Vertical scales are in seconds of two-way traveltime (TWT). This seismic section is the same as one illustrated by Pananont et al. [2004, Figures 6 and 8]. However, their interpretation is different from ours. In particular, they infer a single large extensional fault with $6 \pm$ $1 \mathrm{~km}$ of vertical separation, active during the Oligocene to early Miocene (see text for details).

southern Atacama basin, is thin-skinned. This is indeed apparent on the seismic sections (Figure 13). The detachment can be traced along seismic sections around most of the basin and is in the upper Naranja Formation. This is not surprising, because at outcrop, on the western edge of the basin, the upper Naranja Formation is evaporitic. Toward the north, the detachment becomes deeper, reaching 3 seconds TWT. Here, in contrast with the southern zone, there are two prominent reflectors under the Cordillera de la Sal (Figure 13, see below).

[32] At the western edge of the Salar de Atacama, the Barros Arana syncline is clearly visible on the seismic data (Figure 14), as it is at the surface. Beneath the western limb of the syncline, a strong reflection at about $1.5 \mathrm{~s}$ TWT forms an anticlinal hinge. From good exposures in the Cerro Quimal area, the lower Tonel Formation is in the core of this anticline. Thus the Barros Arana syncline detaches on evaporitic beds of the upper Tonel Formation (see Figures 5,
6, and 14). Between 2.5 and $3 \mathrm{~s}$, another strong reflection also forms an anticlinal hinge. This marker we interpret as the boundary between the lower Tonel Formation and the top of lacustrine Triassic sedimentary rocks. In the upper part of the Purilactis Group, a clear unconformity in the core of the Barros Arana syncline marks the base of OligoceneMiocene gravels (Figures 3 and 14). Thus the structure of the northern Barros Arana syncline appears to be similar to that of the Cerro Quimal area (see Figures 3, 4, 5, 6, and 14), although possibly it has undergone less shortening.

[33] The Barros Arana syncline and the Tonel Formation lie above the continuous strong reflector that marks a regional detachment (Figures 13 and 14). Hence the Barros Arana syncline, the Tonel Formation, and perhaps the Triassic sediments, all overthrust the Paleocene to Neogene sequence. Indeed, Jolley et al. [1990] have already suggested that an eastward verging Frontal Domeyko Thrust has put the Purilactis Group over Neogene strata in the 

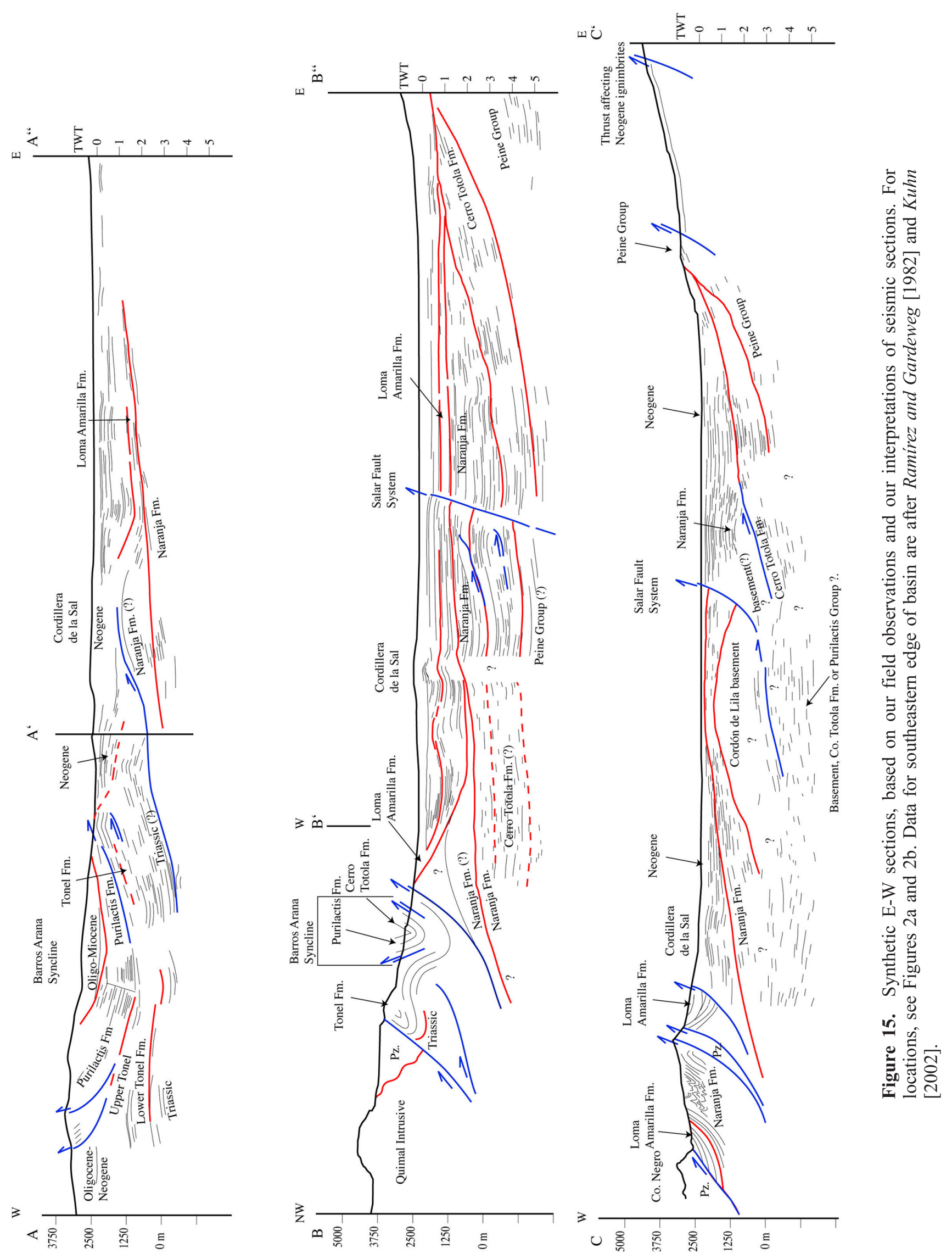

15 of 19 
Barros Arana area. This eastward verging thrust system probably links into the thrust system to the south of Cerro Totola, where the Barros Arana syncline overthrusts the Loma Amarilla syncline (Figure 4).

\section{Discussion}

[34] From our outcrop data and seismic interpretations, we have constructed three structural sections across the Salar de Atacama basin (Figure 15). The main structures are eastward verging thrust sheets. These involve basement in the west and become thin skinned in the east. The intensity of the deformation increases where the basement is directly involved. If the Cordón de Lila basement indeed overthrusts the Cerro Totola Formation, the amount of shortening increases toward the south. However, because of the large tectonic rotations that have been revealed by paleomagnetic studies in this region of the fore arc [Arriagada et al., 2000, 2003], standard methods of section balancing and restoration may not provide good estimates of the amount of shortening.

[35] According to outcrop data at the western edge of the basin, published records for the exploratory well Toconao-1 [Muñoz et al., 1997, 2002] and seismic interpretation, Late Cretaceous to Neogene sequences appear to be continuous across the basin. However, there is no clear evidence that the Purilactis Group (Tonel and Purilactis formations) underlies central parts of the basin. Structural styles and growth strata in the Tonel Formation suggest that at least the lower section of the Purilactis Group accumulated in a compressional setting, next to an eastward verging thrust system. Further work is needed to define the tectonic setting for upper parts of the Purilactis Group.

[36] The thickness of the Paleogene sequence varies strongly, reaching a maximum between the Toconao-1 well and the Cordón de Lila range (Figure 8). Fission track ages for the Cerro Quimal pluton indicate rapid cooling at about $63 \mathrm{Ma}$, probably as a result of exhumation [Andriessen and Reutter, 1994]. Thus the Cordillera Domeyko was a likely source for Paleocene alluvial facies of the Naranja Formation, which accumulated all along the western edge of the basin. On the eastern side of the basin, the Salar Fault System has growth strata of the same age.

[37] An important tectonic event in the area was probably the late Eocene Incaic phase. In our view it accounted for (1) more than $1000 \mathrm{~m}$ of proximal alluvial facies (Loma Amarilla Formation), including growth strata, (2) a regional unconformity, (3) large clockwise tectonic rotations, and (4) uplift and eastward overthrusting of the Cordillera de Domeyko and the Cordón de Lila [Charrier and Reutter, 1994; Andriessen and Reutter, 1994; Maksaev and Zentilli, 1999; Arriagada et al., 2000, 2003].

[38] In contrast with Pananont et al. [2004], we have found no evidence for Oligocene to early Miocene extension. Instead, as discussed above, there is good evidence for Neogene shortening against (1) the western edge of the Salar de Atacama basin, (2) the Salar Fault System, (3) the eastern side of the basin, and (4) the edge of the Western Cordillera [Ramírez and Gardeweg, 1982; Kuhn, 2002].
[39] Thus we argue that the Salar de Atacama basin is a long-lived basin, which developed in a foreland tectonic setting, from the mid-Cretaceous onward. This begs the question as to what happened in surrounding areas. At the scale of continental South America, Cobbold et al. [2006] have summarized evidence for compressional deformation since the mid-Cretaceous all across the continent, from the Andes to the Atlantic margin. However, it is uncommon to find a nearly complete record at any one locality. The two most notable examples are the Salar de Atacama basin, and the Neuquén basin of Argentina. The latter developed in the Andean foreland of northern Patagonia $\left(35^{\circ}\right.$ to $\left.40^{\circ} \mathrm{S}\right)$. The two basins have remarkably similar histories of sedimentation and deformation. In the Neuquén basin [Cobbold and Rossello, 2003], as in the Salar de Atacama basin, the first signs of shortening are growth strata in Aptian evaporites and red sandstones. Subsequent compressional phases, from the Late Cretaceous to the Neogene, were responsible for growth strata in continental clastic sediment.

[40] Within the central Andes, evidence for Late Cretaceous shortening is tenuous, outside the Salar de Atacama basin (see review by Mpodozis et al. [2005]). However, evidence for Paleogene deformation is strong. Within a few hundred kilometers of the Salar de Atacama basin, the presently intramontane basins of the Puna of NW Argentina contain late Eocene to early Oligocene compressional growth strata, which accumulated in a continental foreland setting [Coutand et al., 2001]. In the southern Altiplano basin of Bolivia, shortening peaked in the Oligocene (33$27 \mathrm{Ma}$ ) and Middle to late Miocene (19-8 Ma), after starting on the margins of the plateau in the Eocene [Lamb and Hoke, 1997; Lamb et al., 1997; Elger et al., 2005]. Apparently there was an extensional stage before the early Oligocene, but visible extensional faults show displacements of no more than a few meters [Elger et al., 2005]. In the adjacent Cordillera Oriental of Bolivia, shortening was ongoing from the middle Eocene to the early or middle Miocene [Lamb and Hoke, 1997; Lamb et al., 1997; Müller et al., 2002] and Horton [2005] has identified a formerly widespread foredeep, in which middle Eocene to Oligocene strata accumulated during a period of significant shortening. Overlying the foredeep deposits, late Oligocene to early Miocene strata accumulated in intermontane basins, during a period of less intense shortening. Thus there does not appear to be any clear evidence for deep-seated Cenozoic extension [Lamb and Hoke, 1997; Lamb et al., 1997; Müller et al., 2002].

[41] In the northern part of the present-day outer fore arc of northern Chile, there is good evidence for compressional deformation. In the Arica region $\left(18^{\circ} 30^{\prime} \mathrm{S}\right)$, westward verging thick-skinned thrusts underpin a monoclinal flexure at the western edge of the Altiplano [Isacks, 1988; Muñoz and Charrier, 1996]. In the Aroma region (19³0'S), several such flexures were active between $26 \mathrm{Ma}$ (late Oligocene) and $8 \mathrm{Ma}$, accounting for growth strata at outcrop [Farias et al., 2005]. In the Pica region $\left(20^{\circ}\right.$ to $\left.21^{\circ} \mathrm{S}\right)$, westward verging thrusts were active between about $30 \mathrm{Ma}$ (middle Oligocene) and 10-5 Ma, with maximal rates at $17 \mathrm{Ma}$ [Victor et al., 2004]. All these westward verging structures probably contributed to uplift of the Altiplano. In contrast, 
the structures in the Cordillera de Domeyko and the Salar de Atacama basin have an eastward vergence and so may be anomalous in the present-day fore arc.

[42] Although Pananont et al. [2004] have argued for a late Oligocene to early Miocene phase of extension in the Salar de Atacama Basin, it is clear from the above review that several neighboring areas were undergoing shortening during that same period. Similarly, much further south (between $33^{\circ}$ and $45^{\circ} \mathrm{S}$ ) and in a different context, several authors [e.g., Muñoz et al., 2000; Jordan et al., 2001] have argued for an extensional phase during the late Oligocene to early Miocene, whereas others [e.g., Cobbold and Rossello, 2003] have argued for shortening since the middle Cretaceous. Thus the importance and timing of extensional phases in the building of the Andes remain enigmatic.

[43] The Salar de Atacama basin belongs to a large part of the north Chilean fore arc (between $22^{\circ}$ and $28^{\circ} \mathrm{S}$ ) where clockwise block rotations of as much as $35^{\circ}$ to $40^{\circ}$ occurred mainly during the Eocene to early Oligocene (40-30 Ma), continued to some extent until at least the late Oligocene ( $\sim 25 \mathrm{Ma})$ and terminated before $18 \mathrm{Ma}$ (C. Arriagada et al., submitted manuscript, 2005). Deformation of the Precordillera and clockwise block rotations in the fore arc of northern Chile were coeval with counterclockwise rotations of the fore arc of southern Peru (P. Roperch et al., Counterclockwise rotation of late Eocene-Oligocene forearc deposits in southern Peru and its significance for oroclinal bending in the central Andes, submitted to Tectonics, 2005). The rotations were closely linked to the onset of deformation in the Eastern Cordillera, which led to the building of the central Andes and the formation of the oroclinal bend. On this basis, Paleogene deformation was a major component of Andean orogenesis.

[44] Although in structural style the Salar de Atacama basin resembles a typical foreland basin, it is relatively narrow, deep and long-lived. Loading by the Cordillera de Domeyko and consequent flexural subsidence cannot readily explain such features. Recent geophysical surveys have revealed positive anomalies in the isostatic residual gravity field [Götze and Krause, 2002], which correlate well with the topographic depressions of the Salar de Atacama basin and the Pipanaco basin of northwestern Argentina. Moreover, tomographic data show that the Salar de Atacama is underlain by (1) abnormally dense lithospheric mantle, which may be mechanically coupled with the top of the subducting Nazca plate [Yuan et al., 2002], and (2) a thick and rheologically strong crust, which may have served as a resistant block, around which compressional deformation has nucleated [Schurr and Rietbrock, 2004]. Any of these anomalies could have contributed dynamically to subsidence of the Salar de Atacama basin, so helping to preserve a remnant of the original Andean foreland.

\section{Conclusions}

[45] 1. The Salar de Atacama basin is an anomaly in the present-day fore arc of northern Chile. It contains up to $8 \mathrm{~km}$ of sediment, which accumulated mostly in a foreland setting, next to eastward verging thrusts of the Cordillera de Domeyko.

[46] 2. At the western margin of the basin, incised valleys reveal a thrust wedge, containing a total stratigraphic thickness of up to $5 \mathrm{~km}$ of mid-Cretaceous to Miocene continental sediment. The wedge is thick skinned in the west and thin skinned in the east. Growth strata provide evidence for coeval sedimentation and thrust motions during mid-Cretaceous, Paleogene and Neogene times.

[47] 3. We have correlated outcrop data at the margins of the basin with subsurface data from 2-D seismic reflection surveys and one exploration well (Toconao-1). Paleogene and Neogene sequences appear to be continuous across the basin, even though they vary in thickness. Late Cretaceous clastic sediment of the Purilactis Group may not be so continuous.

[48] 4. From the seismic data, we infer that compressional deformation was coeval with Paleogene and Neogene sedimentation across most of the basin. Thus the Salar de Atacama basin appears to have developed in a foreland setting.

[49] 5. Although our own field observations and interpretation of the seismic lines of the Salar de Atacama basin indicate compressional tectonics, the quality of the seismic data below the complex structure of Cordillera de la Sal is such, that we cannot rule out a possible phase of Oligocene to early Miocene extension, as recently proposed by Pananont et al. [2004]. Thus the current debate about the importance of such a phase in the building of the Andes remains open.

[50] 6. Our results are compatible with those from other areas of the central Andes, including the intramontane basins of the Puna (NW Argentina), the Altiplano basin and Cordillera Oriental of southern Bolivia, and the fore arc of northernmost Chile.

[51] 7. Models that attempt to explain the current thickness of the central Andes should consider Late Cretaceous and Paleogene shortening, as well as the more obvious Neogene and Quaternary shortening.

[52] Acknowledgments. We are particularly grateful to Empresa Nacional del Petróleo-Chile (ENAP) for providing seismic and well data and for permission to publish this paper. Salvador Harambour of ENAP was instrumental in setting up the project. César Arriagada acknowledges funds from CONICYT, FONDECYT (project 3030050) and the Institut de Recherche pour le Développement (IRD), during his bilateral Ph.D. program at Geosciences-Rennes and Universidad de Chile. IRD also funded fieldwork by Peter Cobbold and Pierrick Roperch. The paper has benefited from reviews by José Cembrano.

\section{References}

Allmendinger, R., G. González, J. Yu, G. Hoke, and B. Isacks (2005), Trench-parallel shortening in the northern Chilean forearc: Tectonic and climatic implications, Geol. Soc. Am. Bull., 117, 89-104.
Allmendinger, R. W., T. E. Jordan, S. M. Kay, and B. L. Isacks (1997), The evolution of the Altiplano-Puna Plateau of the central Andes, Annu. Rev. Earth Planet. Sci., 25, 139-174.
Andriessen, P. A. M., and K. J. Reutter (1994), K-Ar and fission track mineral age determination of igneous rocks related to multiple magmatic arc systems along the $23^{\circ} \mathrm{S}$ latitude of Chile and 
NW Argentina, in Tectonics of the Southern Central Andes: Structure and Evolution of an Active Continental Margin, edited by K. J. Reutter, E. Scheuber, and P. Wigger, pp. 141-154, Springer, New York.

Arriagada, C. (1999), Geología y paleomagnetismo del Borde Oriental de la Cordillera de Domeyko entre $\operatorname{los} 22^{\circ} 45^{\prime}$ y $23^{\circ} 30^{\prime}$ latitud sur, II Región, Chile, M.Sc. thesis, 176 pp., Univ. de Chile, Santiago.

Arriagada, C., P. Roperch, and C. Mpodozis (2000), Clockwise block rotations along the eastern border of the Cordillera de Domeyko, northern Chile $\left(22^{\circ} 45^{\prime}-23^{\circ} 30^{\prime} \mathrm{S}\right)$, Tectonophysics, 326, $153-171$.

Arriagada, C., P. R. Cobbold, C. Mpodozis, and P. Roperch (2002), Cretaceous to Paleogene compressional tectonics during deposition of the Purilactis Group, Salar de Atacama, paper presented at Fifth International Symposium on Andean Geodynamics (ISAG), Inst. de Rech. pour le Dév., Toulouse, France.

Arriagada, C., P. Roperch, C. Mpodozis, G. DupontNivet, P. R. Cobbold, A. Chauvin, and J. Cortés (2003), Paleogene clockwise tectonic rotations in the forearc of central Andes, Antofagasta region, northern Chile, J. Geophys. Res., 108(B1),2032, doi:10.1029/2001JB001598.

Baby, P., P. Rochat, G. Mascle, and G. Hérail (1997), Neogene shortening contribution to crustal thickening in the back arc of the central Andes, Geology, $25,883-886$.

Breitkreuz, C., and W. Zeil (1994), The late Carboniferous to Triassic volcanic belt in northern Chile, in Tectonics of the Southern Central Andes: Structure and Evolution of an Active Continental Margin, edited by K. J. Reutter, E. Scheuber, and P. Wigger, pp. 277-292, Springer, New York.

Charrier, R., and K. J. Reutter (1994), The Purilactis group of northern Chile: Boundary between arc and backarc from Late Cretaceous to Eocene, in Tectonics of the Southern Central Andes: Structure and Evolution of an Active Continental Margin, edited by K. J. Reutter, E. Scheuber, and P. Wigger, pp. 189-202, Springer, New York

Chong, G., and K. J. Reutter (1985), Fenómenos de tectónica compresiva en las Sierras de Varas y de Argomedo, Precordillera Chilena, en ámbito del Paralelo $25^{\circ}$ sur, paper presented at IV Congreso Geológico Chileno, Univ. Católica del Norte, Antofagasta, Chile.

Cobbold, P. R., and E. A. Rossello (2003), Aptian to recent compressional deformation, foothills of the Neuquén Basin, Argentina, Mar. Pet. Geol., 20, 429-443.

Cobbold, P. R., E. A. Rossello, P. Roperch, C. Arriagada, L. A. Gómez, and C. Lima (2006), Distribution and timing of Andean deformation across South America, in Global Tectonic Processes: The legacy of Mike Coward, edited by A. Ries, R. H. Graham, and R. W. Butler, Geol. Soc. Spec. Publ., in press.

Coney, P. J., and C. A. Evenchick (1994), Consolidation of the American Cordilleras, J. S. Am. Earth Sci., 7, 241-262.

Coutand, I., P. R. Cobbold, M. de Urreiztieta, P. Gautier, A. Chauvin, D. Gapais, E. A. Rossello, and O. López-Gamundí (2001), Style and history of Andean deformation, Puna plateau, northwestern Argentina, Tectonics, 20, 210-234.

Damm, K. W., S. Pichowiak, C. Breitkreuz, R. S. Harmon, W. Todt, and M. Buchelt (1991), The Cordon de Lila Complex, central Andes, northern Chile: An Ordovician continental volcanic province, in Andean Magmatism and Its Tectonic Setting, edited by R. S. Harmon and C. W. Rapela, Spec. Pap. Geol. Soc. Am., 265, 179-187.

DeMets, C., R. G. Gordon, D. F. Argus, and S. Stein (1994), Effect of recent revisions to the geomagnetic reversal time scale on estimates of current plate motions, Geophys. Res. Lett., 21, 2191 -2194.

Dewey, J. F., and J. M. Bird (1970), Mountain belts and the new global tectonics, J. Geophys. Res., 75, $2625-2647$.
Dingman, R. J. (1963), Cuadrángulo Tulor, Provincia de Antofagasta, scale 1:150,000, Carta Geol. Chile, $11,35 \mathrm{pp}$.

Elger, K., O. Oncken, and J. Glodny (2005), Plateaustyle accumulation of deformation: Southern Altiplano, Tectonics, 24, TC4020, doi:10.1029/ 2004TC001675.

Farías, M., R. Charrier, D. Comte, J. Martinod, and G. Hérail (2005), Late Cenozoic deformation and uplift of the western flank of the Altiplano: Evidence from the depositional, tectonic, and geomorphologic evolution and shallow seismic activity (northern Chile at $19^{\circ} 30^{\prime} \mathrm{S}$ ), Tectonics, 24, TC4001, doi:10.1029/2004TC001667.

Flint, S., P. Turner, E. J. Jolley, and A. J. Hartley (1993), Extensional tectonics in convergent margin basins: An example from the Salar de Atacama, Chilean Andes, Geol. Soc. Am. Bull., 105, 603-617.

Galliski, M. A., and J. G. Viramonte (1988), The Cretaceous paleorift in northwestern Argentina: A petrologic approach, J. S. Am. Earth Sci., 1, $329-342$.

Gephart, J. W. (1994), Topography and subduction geometry in the central Andes: Clues to the mechanics of a noncollisional orogen, J. Geophys. Res., 99, $12,279-12,288$.

González, G., J. Cembrano, D. Carrizo, A. Macci, and H. Schneider (2003), The link between forearc tectonics and Pliocene-Quaternary deformation of the Coastal Cordillera, northern Chile, J. S. Am. Earth Sci., 16, 321-342.

Götze, H.-J., and S. Krause (2002), The central Andean gravity high, a relic of an old subduction complex? J. S. Am. Earth Sci., 14, 799-811.

Gubbels, T. L., B. L. Isacks, and E. Farrar (1993), High level surfaces, plateau uplift, and foreland development, Bolivian central Andes, Geology, 21, 695698

Hammerschmidt, K., R. Döbel, and H. Friedrichsen (1992), Implication of ${ }^{40} \mathrm{Ar} /{ }^{39} \mathrm{Ar}$ dating of Tertiary volcanics rocks from the north-Chilean Precordillera, Tectonophysics, 202, 55-81.

Hartley, A. J., S. Flint, P. Turner, and E. J. Jolley (1992), Tectonic controls on the development of semiarid, alluvial basin as reflected in the stratigraphy of the Purilactis Group (upper CretaceousEocene), northern Chile, J. S. Am. Earth Sci., 5, $275-296$.

Horton, B. K. (2005), Revised deformation history of the central Andes: Inferences from Cenozoic foredeep and intermontane basins of the Eastern Cordillera, Bolivia, Tectonics, 24, TC3011, doi:10.1029/2003TC001619.

Horton, B. K., and P. G. DeCelles (1997), The modern foreland basin system adjacent to the central Andes, Geology, 25, 895-898.

Horton, B. K., B. A. Hampton, and G. L. Waanders (2001), Paleogene synorogenetic sedimentation in the Altiplano plateau and implications for initia mountain building in the central Andes, Geol. Soc. Am. Bull., 113, 1387-1400.

Isacks, B. L. (1988), Uplift of the central Andean plateau and bending of the Bolivian orocline, J. Geophys. Res., 93, 3211-3231.

James, D. (1971), Andean crustal and upper mantle structure, J. Geophys. Res., 76, 3246-3271.

Jolley, E. J., P. Turner, G. D. Williams, A. J. Hartley, and S. Flint (1990), Sedimentological response of an alluvial system to Neogene thrust tectonics, Atacama Desert, northern Chile, J. Geol. Soc. London, 147, 769-784

Jordan, T., W. M. Burns, R. Veiga, F. Pángaro, P. Copeland, S. Kelley, and C. Mpodozis (2001), Extension and basin formation in the southern Andes caused by increased convergence rate: A mid-Cenozoic trigger for the Andes, Tectonics, 20, 308-324.

Jordan, T. E., N. Muñoz, M. Hein, T. Lowenstein, L. Godfrey, and J. Yu (2002), Active faulting and folding without topographic expression in an evaporite basin, Chile, Geol. Soc. Am. Bull., $114,1406-1421$
Kley, J. (1999), Geologic and geometric constraints on a kinematic model of the Bolivian orocline, J. S Am. Earth Sci., 12, 221-235.

Kuhn, D. (2002), Fold and thrust belt structures and strike-slip faulting at the SE margin of the Salar de Atacama basin, Chilean Andes, Tectonics, 21(4), 1026, doi:10.1029/2001TC901042.

Lamb, S., and L. Hoke (1997), Origin of the high plateau in the central Andes, Bolivia, South America, Tectonics, 16, 623-649.

Lamb, S., L. Hoke, L. Kennan, and J. Dewey (1997), Cenozoic evolution of the central Andes in Bolivia and northern Chile, in Orogeny Through Time, edited by J.-P. Burg and M. Ford, Geol. Soc. Spec. Publ., 121, 237-264.

Macellari, C. E., M. J. Su, and F. Townsend (1991), Structure and seismic stratigraphy of the Atacama Basin, northern Chile, paper presented at VI Congreso Geológico Chileno, Univ. de Chile, Viña del Mar, Chile.

Maksaev, V., and M. Zentilli (1999), Fission track thermochronology of the Domeyko Cordillera, northern Chile: Implications for Andean tectonics and porphyry copper metallogenesis, Explor. Min. Geol., 8 , $65-89$.

Marquillas, R., and J. A. Salfity (1994), Relaciones estratigráficas regionales de la Formación Yacoraite (Cretácico Superior), norte de la Argentina, paper presented at VII Congreso Geológico Chileno, Univ. de Concepción, Concepción, Chile.

McQuarrie, N., and P. DeCelles (2001), Geometry and structural evolution of the central Andean backthrust belt, Bolivia, Tectonics, 20, 669-692.

Mpodozis, C., C. Arriagada, and P. Roperch (1999), Cretaceous to Paleogene geology of the Salar de Atacama basin, northern Chile: A reappraisal of the Purilactis Group stratigraphy, paper presented at Fourth International Symposium on Andean Geodynamics (ISAG), Inst. de Rech. pour le Dév., Göttingen, Germany.

Mpodozis, C., C. Arriagada, M. Basso, P. Roperch, P. Cobbold, and M. Reich (2005), Late Mesozoic to Paleogene stratigraphy of the Salar de Atacama basin, Antofagasta, northern Chile: Implications for the tectonic evolution of the central Andes, Tectonophysics, 399, 125-154.

Müller, J. P., J. Kley, and V. Jacobshagen (2002), Structure and Cenozoic kinematics of the Eastern Cordillera, southern Bolivia $\left(21^{\circ} \mathrm{S}\right)$, Tectonics, 21(5), 1037, doi:10.1029/2001TC001340.

Muñoz, J., R. Troncoso, P. Duhart, P. Crignola, L. Farmer, and C. R. Stern (2000), The relation of the mid-Tertiary coastal magmatic belt in south-central Chile to the late Oligocene increase in plate convergence rate, Rev. Geol. Chile, 27, $177-203$.

Muñoz, N., and R. Charrier (1996), Uplift of the western border of the Altiplano on a west-vergent thrust system, northern Chile, J. S. Am. Earth Sci., 9, $171-181$

Muñoz, N., R. Charrier, and J. K. Reutter (1997), Evolución de la Cuenca del Salar de Atacama: Inversión tectónica y relleno de una cuenca de antepaís de retroarco, paper presented at VIII Congreso Geológico Chileno, Univ. Católica del Norte, Antofagasta, Chile.

Muñoz, N., T. E. Jordan, and R. Charrier (2002), Interactions between basement and cover during the evolution of the Salar de Atacama basin, northern Chile, Rev. Geol. Chile, 29, 3-29.

Naranjo, J. A., C. F. Ramírez, and R. Paskoff (1994), Morphostratigraphic evolution of the northwestern margin of the Salar de Atacama basin $\left(23^{\circ} \mathrm{S}-\right.$ $\left.68^{\circ} \mathrm{W}\right)$, Rev. Geol. Chile, 21, $91-103$.

Niemeyer, R. H. (1984), La megafalla Tucucaro en el extremo Sur del Salar de Atacama: Una antigua zona de cizalla reactivada en el Cenozoico, Ser. $\mathrm{Co}$ mún. 34, pp. 37-45, Dep. Geol., Fac. de Cienc. Fís. y Mat., Univ. de Chile, Santiago.

Norabuena, E., L. Leffler-Griffin, A. Mao, T. Dixon, S. Stein, I. S. Sacks, L. Ocola, and M. Ellis (1997), Space geodetic observations of Nazca- 
South America convergence across the central Andes, Science, 279, 358-362.

Pananont, P., C. Mpodozis, N. Blanco, T. E. Jordan, and L. D. Brown (2004), Cenozoic evolution of the northwestern Salar de Atacama Basin, northern Chile, Tectonics, 23, TC6007, doi:10.1029/ 2003TC001595.

Ramírez, C. F., and M. Gardeweg (1982), Hoja Toconao; Región de Antofagasta, 1:250,000, Carta Geol. Chile, 54, 122 pp.

Randall, D. E., A. J. Tomlinson, and G. K. Taylor (2001), Paleomagnetically defined rotations from the Precordillera of northern Chile: Evidence of localized in situ fault-controlled rotations, Tectonics, 20, 235-254

Salfity, J. A. (1985), Lineamentos transversales al Rumbo Andino en el noroeste Argentino, paper presented at IV Congreso Geológico Chileno, Univ. Católica del Norte, Antofagasta, Chile.

Scheuber, E., and K. J. Reutter (1992), Magmatic arc tectonics in the central Andes between $21^{\circ}$ and $25^{\circ}$, Tectonophysics, 205, 127-140.

Schmitz, M. (1994), A balanced model of the southern central Andes, Tectonics, 13, 484-492.

Schurr, B., and A. Rietbrock (2004), Deep seismic structure of the Atacama basin, northern Chile, Geophys. Res. Lett., 31, L12601, doi:10.1029/ 2004GL019796.
Semperé, T. (1995), Phanerozoic evolution of Bolivia and adjacent regions, in Petroleum Basins of South America, edited by A. J. Tankard, R. Suarez, an H. J. Welsink, AAPG Mem., 62, 207-230.

Semperé, T., G. Hérail, J. Oller, and M. G. Bonhomme (1990), Late Oligicene-early Miocene major tectonic crisis and related basins in Bolivia, Geology, $18,946-949$

Semperé, T., R. F. Butler, D. R. Richards, L. G. Marshall, W. Sharp, and C. C. Swisher II (1997), Stratigraphy and chronology of Upper Cretaceous-lower Paleogene strata in Bolivia and northwest Argentina, Geol. Soc. Am. Bull., 109, 709-727

Sheffels, B. M. (1990), Lower bound on the amount of crustal shortening in the central Bolivian Andes, Geology, 18, 812-815.

Somoza, R., and A. Tomlinson (2002), Paleomagnetism in the Precordillera of northern Chile $\left(22^{\circ} 30^{\prime} \mathrm{S}\right)$ Implications for the history of tectonic rotations in the central Andes, Earth Planet. Sci. Lett., 194 $369-381$.

Somoza, R., S. Singer, and A. Tomlinson (1999), Paleomagnetic study of upper Miocene rocks from northern Chile: Implications for the origin of late Miocene-Recent tectonic rotations in the souther central Andes, J. Geophys. Res., 104, 22,92322,936
Victor, P., O. Oncken, and J. Glodny (2004), Uplift of the western Altiplano plateau: Evidence from the Precordillera between $20^{\circ}$ and $21^{\circ} \mathrm{S}$ (northern Chile), Tectonics, 23, TC4004, doi:10.1029 2003TC001519.

Wilkes, E., and K. Görler (1994), Sedimentary and structural evolution of the Salar de Atacama Depression, in Tectonics of the Southern Central Andes: Structure and Evolution of an Active Continental Margin, edited by K. J. Reutter, E. Scheuber, and P. Wigger, pp. 117-188, Springer, New York.

Yuan, X., S. V. Sobolev, and R. Kind (2002), Moho topography in the central Andes and its geodynamic implications, Earth Planet. Sci. Lett., 199, 389402.

C. Arriagada, Departamento de Geología, Universidad de Chile, Plaza Ercilla 803, Santiago, Chile.

P. R. Cobbold and P. Roperch, GéosciencesRennes, UMR6118 du CNRS, Campus de Beaulieu, F-35042 Rennes Cedex, France. (peter.cobbold@ univ-rennes1.fr) 